\title{
A newly recognized clade of trans-Andean Oryzomyini (Rodentia: Cricetidae), with description of a new genus
}

\author{
Ronald H. Pine, Robert M. Timm,* and Marcelo Weksler \\ Division of Mammals, Field Museum of Natural History, 1400 S Lake Shore Drive, Chicago, IL 60605, USA (RHP) \\ Biodiversity Institute, 1345 Jayhawk Boulevard, University of Kansas, Lawrence, KS 66045, USA (RHP) \\ Department of Ecology \& Evolutionary Biology and Biodiversity Institute, 1345 Jayhawk Boulevard, University of \\ Kansas, Lawrence, KS 66045, USA (RMT) \\ Mammalogy, Department of Vertebrates, Museu Nacional-Universidade Federal do Rio de Janeiro, Rio de Janeiro, Rio \\ de Janeiro 20940-040, Brazil (MW)
}

*Correspondent: btimm@ku.edu

\begin{abstract}
We expand upon recent studies on relationships within the Oryzomyini, in particular, those involving taxa currently assigned to the genus Sigmodontomys. In recent years, Sigmodontomys has been treated as including 2 species, alfari (J. A. Allen, 1897) and aphrastus (Harris, 1932), but throughout their complicated taxonomic history both species also have been placed in the genus Oryzomys, and alfari independently in Nectomys. Using morphological (98 external, cranial, dental, and postcranial) and molecular (nuclear interphotoreceptor retinoid-binding protein gene and mitochondrial cytochrome- $b$ and ribosomal 12S RNA genes) characters, we infer the phylogenetic position of these 2 species within Oryzomyini. We document that alfari and aphrastus do not form a monophyletic group. Sigmodontomys alfari is most closely related to Melanomys, and aphrastus is either the sister to that clade, or to the extinct Caribbean genus Megalomys. Thus, aphrastus is best regarded as representing a new genus, which is described and named herein. This new genus falls within the Sigmodontomys-Melanomys-Aegialomys-Nesoryzomys clade, which forms a monophyletic group of mainly southern Central American and northern South American taxa primarily restricted to lowland to midelevation montane trans-Andean habitats and possessing a marked ability to cross expanses of salt water. The new genus occurs at middle elevations from north-central Costa Rica to northwestern Ecuador and along with some populations of Aegialomys and Melanomys occupies the highest elevations for members of this group.
\end{abstract}

Key words: cytochrome $b, 12 \mathrm{~S}$ gene, interphotoreceptor retinoid-binding protein [IRBP], mitochondrial genes, Neotropics, nuclear gene, phylogeny, Sigmodontinae, Sigmodontomys, Tanyuromys

(C) 2012 American Society of Mammalogists

DOI: 10.1644/11-MAMM-A-012.1

The rodent family Cricetidae is one of the most diverse mammalian families, including more than 130 genera divided into 6 subfamilies-Arvicolinae, Cricetinae, Lophiomyinae, Neotominae, Sigmodontinae, and Tylomyinae (Jansa and Weksler 2004; Musser and Carleton 2005; Steppan et al. 2004). The Sigmodontinae, a New World lineage, is the largest cricetid subfamily, both in numbers of described genera and of species, with 83 extant and several extinct genera recognized (D'Elía et al. 2007; Musser and Carleton 2005; Pardiñas et al. 2002; Percequillo et al. 2011; Weksler and Percequillo 2011; Weksler et al. 2006). Within the Sigmodontinae, the tribe Oryzomyini, a well-supported clade consisting of 27 extant and 5 extinct recognized genera, occurs from the northeastern United States through Mexico and Central America to southernmost South America, as well as to Bonaire and Curaçao, the Greater and eastern Lesser Antilles (all extinct), the Fernando de Noronha Archipelago, and the Galapagos Islands (hereafter, Galapagos [Carleton and Olson 1999; Pardiñas 2008; Percequillo et al. 2011; Turvey et al. 2010; Weksler et al. 2006; Zijlstra et al. 2010]). The extinct genera of Oryzomyini currently recognized include Carletonomys Pardiñas, 2008 (Argentine pampas; early or middle Pleistocene); Megalomys Trouessart, 1881 (Barbuda, Curaçao, Martinique, and Saint Lucia; historic times); Noronhomys Carleton and Olson, 1999 (Ilha Fernando de Noronha, Brazil; late Quaternary and perhaps historic times); Pennatomys Turvey et al., 2010 (Nevis, St. Eustatius, and St. Kitts, Lesser Antilles; late Holocene and perhaps still extant, see 'Discussion'); and Agathaeromys Zijlstra, Madern, and van den Hoek Ostende, 2010 (Bonaire; middle to late Pleistocene).

w w w. m a m ma log y. org 
Among the most poorly known of the currently recognized and extant genera of Oryzomyini is Sigmodontomys J. A. Allen, 1897. As presently constituted, Sigmodontomys contains 2 species: alfari (J. A. Allen, 1897) and aphrastus (Harris, 1932). Both species are poorly known and have been the subject of considerable taxonomic debate. The published reports of aphrastus are based on only 8 specimens; the holotype from west-central Costa Rica, 2 recently collected specimens from northwestern Costa Rica, 2 specimens from Panama, and 3 from Ecuador (Lee et al. 2010; McCain et al. 2007; Méndez 1993; Musser and Williams 1985; Voss 1988). Harris (1932:5) named Oryzomys aphrastus on the basis of a single adult female from Costa Rica, taken by Austin Smith. Especially noteworthy in Harris's brief description is the detailed account of the coloration of the pelage and his observation that the molars have "prominent cusps and deep re-entrant angles." The description contained no comparisons with other species and no skull measurements, and gave merely 3 external measurements taken by Smith in the field. Ellerman $(1941: 345,349)$ assigned aphrastus to the subgenus Oryzomys Baird, 1857; however, he did not place it in any of the species groups that he recognized. Hershkovitz (1944:73) was the 1st to compare aphrastus with Sigmodontomys alfari (called Nectomys alfari at that time), and noted significant differences, stating:

The most striking resemblance to alfari is noted in the atypical Oryzomys aphrastus. Externally, it is distinguished from alfari by its darker color, finer pelage, the greater length of its tail (extreme for an oryzomyine rodent), and by the longer fifth hind toe which reaches to base of second phalanx of the fourth toe. Cranially, aphrastus is distinguished chiefly by its narrower interorbital region, the greater attenuation of the nasals posteriorly (quite as in $N$ [ectomys]. squamipes), the weaker, narrower zygomatic plate, and, especially, by the even larger size of its cheek teeth, which attain here a maximum in size and complexity among oryzomyine rodents. In aphrastus, the greatest width of $m^{1}$ is nearly equal to the shortest distance across the palate between each of the first molars.

Goodwin (1946:394) provided a brief redescription of Harris's single specimen, gave 5 skull measurements, and was the 1st to note its external resemblance to Nephelomys devius (Bangs, 1902), but stated, regarding aphrastus, "its longer tail and larger and broader feet readily distinguish it from the latter [N. devius]." Later, Hershkovitz (1948:56) stated that "The Costa Rican Oryzomys aphrastus ... is probably most nearly related to $O$. [now Mindomys] hammondi." Reconsidering, Hershkovitz (1970:792) wrote that hammondi "is not nearly related to the semiaquatic Oryzomys aphrastus as I suggested in 1948." The habitats recorded for aphrastus, along with its external anatomy, show that it is not semiaquatic, contra Hershkovitz (1970:792), and Tirira (2008:120), who called this species the "Long-tailed Rice Water Rat.' Hall and Kelson (1959:565) quoted Harris's original description in part and placed aphrastus in the subgenus Oryzomys, but stated that "The systematic position of this 'species' is doubtful. Our assignment of it to the 'devius-group' is provisional.' Hall (1981:618) amended the treatment by Hall and Kelson (1959), dispensing altogether with species groups in the subgenus Oryzomys and stating “'This 'species' is provisionally placed between $O$. albigularis and O. capito." Ray (1962:110) stated "I have compared directly the unique type skull $\ldots$ and find that $O$. aphrastus is an immature Nectomys, close to if not conspecific with Nectomys alfari." Contra Ray (1962), our study of the type proves it to be an adult. Musser and Carleton (1993:748, 2005:1178) provisionally treated alfari and aphrastus as the sole members of the genus Sigmodontomys, stating that the relationships to Oryzomys need to be refined and that "Assignment to Sigmodontomys tentative following the observations of Ray ... ." Carleton and Musser (1995:358) suggested that Hershkovitz's initial assessment might be correct; "aphrastus actually may bear closer kinship to another enigmatic, little known species, Oryzomys [now Mindomys] hammondi of northwestern Ecuador" than it does to Sigmodontomys alfari. Mindomys hammondi (Thomas, 1913) remains poorly known, is represented in collections by few specimens, and the genus is considered to be monotypic.

Weksler (2006), in a study of phylogenetic relationships among the Oryzomyini, using both morphological and molecular data, found that alfari and aphrastus were not sister taxa, but rather that Melanomys Thomas, 1902, was the sister to alfari, with aphrastus the next group out. Nectomys apicalis Peters, 1861, and N. squamipes (Brants, 1827) plus Amphinectomys Malygin, 1994, formed the sister group to this clade. At the time of Weksler's study, however, no fresh tissue of aphrastus was available for genetic analysis and thus his analyses for that species were based on morphological characters only. Based on this database, Weksler et al. (2006) described 10 new genera from within the polyphyletic genus Oryzomys. Independently, based on analysis of nucleotide sequences of the mitochondrial DNA cytochrome- $b$ gene (Cytb), Hanson and Bradley (2008) found Sigmodontomys alfari to be well nested within Melanomys, rendering the latter paraphyletic; aphrastus was not included in their analysis.

In light of the considerable controversy that has attended the taxonomy of alfari and aphrastus, and based on our own research on pertinent specimens, we herein: reassess the relationships of alfari and aphrastus, using morphological and molecular data; incorporate both data sets to evaluate the taxonomic arrangement that best reflects the relationships of these species; and relate our conclusions to the biogeography of this clade. We herein confirm that alfari and aphrastus are not sister taxa and that aphrastus is best regarded as representing a distinct new genus, as described below.

\section{Materials and Methods}

Morphological characters and taxon sampling.-We examined 7 of the 8 known specimens referred to aphrastus. Detailed external and cranial comparisons were made between these and all recognized genera of Oryzomyini (in a very few cases, comparisons were made with published accounts only): 
Aegialomys Weksler, Percequillo, and Voss, 2006; Agathaeromys; Amphinectomys; Carletonomys; Cerradomys Weksler, Percequillo, and Voss, 2006; Drymoreomys Percequillo, Weksler, and Costa, 2011; Eremoryzomys Weksler, Percequillo, and Voss, 2006; Euryoryzomys Weksler, Percequillo, and Voss, 2006; Handleyomys Voss, Gómez-Laverde, and Pacheco, 2002; Holochilus Brandt, 1835; Hylaeamys Weksler, Percequillo, and Voss, 2006; Lundomys Voss and Carleton, 1993; Megalomys; Melanomys; Microryzomys Thomas, 1917; Mindomys Weksler, Percequillo, and Voss, 2006; Neacomys Thomas, 1900; Nectomys Peters, 1861; Nephelomys Weksler, Percequillo, and Voss, 2006; Nesoryzomys Heller, 1904; Noronhomys; Oecomys Thomas, 1906; Oligoryzomys Bangs, 1900; Oreoryzomys Weksler, Percequillo, and Voss, 2006; Oryzomys; Pennatomys; Pseudoryzomys Hershkovitz, 1962; Scolomys Anthony, 1924; Sigmodontomys alfari; Sooretamys Weksler, Percequillo, and Voss, 2006; Transandinomys Weksler, Percequillo, and Voss, 2006; and Zygodontomys J. A. Allen, 1897. New morphological character information for aphrastus was combined with that already available for the taxon, and includes phallic and other soft-tissue characters for a total of 98 characters as defined in Weksler (2006) and Percequillo et al. (2011). Reanalysis of certain morphological characters given by Weksler (2006) is provided elsewhere (McCain et al. 2007; Percequillo et al. 2011; Turvey et al. 2010; Voss and Weksler 2009; Weksler et al. 2006). Terminology for and illustrations of the characters described here have been given by Hooper and Musser (1964), Carleton (1973, 1980), Reig (1977), Voss and Linzey (1981), Voss (1988, 1993), Carleton and Musser (1989), Voss and Carleton (1993), Steppan (1995), and Weksler (2006). All capitalized color terms are from Ridgway (1912). We include 6 additional terminal taxa not treated in Weksler's (2006) original analysis. These are Rhipidomys nitela Thomas, 1901, as an additional outgroup; Drymoreomys, a newly recognized genus of Oryzomyini (Percequillo et al. 2011); 2 species of the extinct Antillean genus Megalomys, M. desmarestii (Fischer, 1829) and M. luciae (Major, 1901), which were found as members of a Sigmodontomys-Melanomys-Nectomys clade in a recent cladistic analysis (Turvey et al. 2010); and 2 additional species of Melanomys, M. chrysomelas (J. A. Allen, 1897) and M. columbianus (J. A. Allen, 1899), in order to assess the monophyly of Melanomys vis-à-vis Sigmodontomys alfari as per Hanson and Bradley's (2008) analyses. The interphotoreceptor retinoid-binding protein [IRBP] sequence data for the specimen identified as Melanomys caliginosus (Tomes, 1860) by Weksler (2003), from Venezuela, is treated here as $M$. columbianus (Appendix I), based on the results of morphological analysis of material deposited in the American Museum of Natural History (M. Weksler and S. Loss, Museu Nacional-Universidade Federal do Rio de Janeiro, pers. comm.) and on the molecular results of Hanson and Bradley (2008). The extinct genera Agathaeromys, Carletonomys, Noronhomys, and Pennatomys are not included in this analysis because they are represented by very sparse material or are not closely related to the Sigmodontomys-Melanomys clade, or both (Carleton and Olson 1999; Pardiñas 2008; Turvey et al. 2010; Zijlstra et al. 2010).

A detailed list of pertinent species studied and specimens examined can be found in Weksler (2006); additional specimens were listed by McCain et al. (2007), Turvey et al. (2010 [Megalomys]), and Percequillo et al. (2011 [Drymoreomys]). Specimens of newly analyzed taxa are presented in Appendix I. Specimens from the following institutions were used in this study: American Museum of Natural History, New York, New York (AMNH); Field Museum, Chicago, Illinois (FMNH); Museo Nacional de Costa Rica, San José, Costa Rica (MNCR); Museum of Comparative Zoology, Harvard University, Cambridge, Massachusetts (MCZ); Museum of Vertebrate Zoology, University of California, Berkeley, California (MVZ); National Museum of Natural History, Washington, D.C. (USNM); Natural History Museum, London, United Kingdom; University of Kansas Natural History Museum, Lawrence, Kansas (KU); and University of Michigan Museum of Zoology, Ann Arbor, Michigan (UMMZ). One specimen of aphrastus (KU 159021), obtained at Monteverde, Costa Rica, will be deposited in MNCR.

This project was undertaken with the approval of the University of Kansas Institutional Animal Care and Use Committee. All animal handling protocols were in accordance with guidelines of the American Society of Mammalogists (Sikes et al. 2011).

Molecular techniques.-Amplification and sequencing of the nuclear IRBP and mitochondrial (Cytb) fragments followed Weksler (2003) and Percequillo et al. (2011), respectively. For ribosomal 12S RNA gene sequences, DNA was isolated from tissue samples preserved in ethanol, using DNeasy and Puregene extraction kits (QIAGEN Inc., Valencia, California). A fragment of the $12 \mathrm{~S}$ gene was amplified with primers L1091 and H1478 of Kocher et al. (1989), using standard polymerase chain reaction procedures. Amplifications were performed as 20- $\mu$ l reactions using Amplitaq Gold PCR Mastermix (PerkinElmer, Boston, Massachusetts) and recommended concentrations of primers and templates. Reactions were performed for 35 polymerase chain reaction cycles of denaturation at $95^{\circ} \mathrm{C}$ for $20 \mathrm{~s}$, annealing at $55^{\circ} \mathrm{C}$ for $15 \mathrm{~s}$, and extension at $72^{\circ} \mathrm{C}$ for $60 \mathrm{~s}$. After purification, polymerase chain reaction products were sequenced with the same primers used in the polymerase chain reaction amplification. Nucleotide sequences were determined using automated sequencers ABI 3100 or ABI 3130xl (Life Technologies, Grand Island, New York). Fragments of the $12 \mathrm{~S}$ sequences varied in length from 382 to 391 base pairs (bp) with variation due to 4 insertion-deletion (indel) regions between bases 21 and 31, 197 and 206, 226 and 236, and 297 and 312. The insertion of gaps between these intervals for phylogenetic analyses was ambiguous, and removed prior to all analyses, resulting in a fragment of $349 \mathrm{bp}$ (analyses with fragments did not change any strongly supported node presented here). All resulting new sequences have been deposited in GenBank (accession numbers JF693827-JF693878) and incorporated into a data matrix containing previously published sequences (Appendix II; Bonvicino and Moreira 2001; Percequillo et al. 
2011; Weksler 2003, 2006). A Nexus file with complete character matrix used for all analyses is available at http://www. morphobank.org (project id $=177$ ).

Phylogenetic analysis.-Morphological characters and DNA sequences were subjected to phylogenetic analyses using maximum parsimony (Farris 1983; Swofford et al. 1996), maximum likelihood (Felsenstein 1981, 2003; Swofford et al. 1996), and Bayesian inference (Huelsenbeck et al. 2001; Yang and Rannala 1997). The data sets were used in combined and separated analyses. Parsimony and Bayesian analyses were employed for the total combined supermatrix and for each individual data set. Maximum-likelihood analyses were used for each gene individually and for the combined molecular supermatrix. In the parsimony analysis, characters were equally weighted. Sequence characters were always treated as unordered, but some multistate morphological characters were ordered as described by Weksler (2006). We employed the "polymorphic" coding of Wiens (1995) for characters with intraspecific variation.

The heuristic search algorithm implemented by PAUP* version 4.0b10 (Swofford 2001) was used in all parsimony analyses. Each heuristic search employed 1,000 replicates of random taxon addition with tree-bisection-reconnection branch swapping; clades with at least 1 unambiguous synapomorphy were the only ones retained. Jackknife values (Farris et al. 1996) for the parsimony analyses were calculated using 1,000 pseudoreplicates, with heuristic searches employed within each replicate $(36.8 \%$ character removal per replicate; 10 random addition replicates, tree-bisectionreconnection branch swapping, and no more than 100 trees saved per replicate). The general time reversible (GTR) model of nucleotide substitution (Rodríguez et al. 1990), corrected for site-specific rate heterogeneity, using the gamma distribution with 4 classes (Yang 1994), was used in all likelihood and Bayesian analyses. Gene-specific unlinked models were employed in the analysis of combined data sets. Base frequencies were empirically estimated from the data. The maximum-likelihood trees were calculated using RAxML (Stamatakis 2006b). Nodal bootstrap values for the likelihood analysis were calculated using 1,000 pseudoreplicates, under the GTRCAT model in RAxML (Felsenstein 1985; Stamatakis 2006a). Bayesian analyses were performed using Markov chain Monte Carlo sampling as implemented in MrBayes 3.1 (Huelsenbeck and Ronquist 2001; Ronquist and Huelsenbeck 2003). Uniform interval priors were assumed for all parameters except base composition, for which we assumed a Dirichlet prior. The parsimony model of Lewis (2001) was used for the morphological characters. We performed 4 independent runs of 10,000,000 generations each, with 2 heated chains sampling for trees and parameters every 10,000 generations. The first 2,500,000 generations were discarded as burn-in, and the remaining trees were used to estimate posterior probabilities for each node. All analyses were checked for convergence by plotting the log-likelihood values against generation time for each run, using Tracer 1.4 (Rambaut and Drummond 2007). All parameters have effective sample sizes greater than 200 .

\section{RESUlts}

Phylogenetic analyses.-Sigmodontomys alfari and "S." aphrastus are not recovered herein as sister taxa in the analyses of combined data sets, regardless of methodological approach. The concatenated matrix of morphological and molecular data provided 1,177 variable and 856 potentially parsimonyinformative characters (morphology, 89; Cytb, 476; IRBP, $210 ; 12 \mathrm{~S}, 81$ ). Bayesian analyses of all combined data resulted in a tree with a high proportion of nodes with high posterior probability $(>0.95$; Fig. 1). The estimated model parameters are: (values for IRBP/12S/Cytb): $\mathrm{r}(\mathrm{A} \leftrightarrow \mathrm{C}): 0.086 / 0.035 / 0.013, \mathrm{r}(\mathrm{A} \leftrightarrow \mathrm{G}): 0.370 /$ 0.278/0.205, $\mathrm{r}(\mathrm{A} \leftrightarrow \mathrm{T}): 0.043 / 0.087 / 0.044, \mathrm{r}(\mathrm{C} \leftrightarrow \mathrm{G}): 0.039 / 0.016 /$ 0.009, $\mathrm{r}(\mathrm{C} \leftrightarrow \mathrm{T}): 0.421 / 0.555 / 0.692, \mathrm{r}(\mathrm{G} \leftrightarrow \mathrm{T}): 0.041 / 0.028 / 0.038$; freq: pi(A): 0.227/0.370/0.414, pi(C): 0.268/0.206/0.309, pi(G): 0.275/0.147/0.069, pi(T): 0.231/0.276/0.208; alpha: 0.402/0.180/ 0.200; alpha (morphology): 1.253. Overall, this tree has similar structure to previous phylogenetic results for the Oryzomyini (Percequillo et al. 2011; Turvey et al. 2010; Voss and Weksler 2009; Weksler 2003, 2006). Thus, the Oryzomyini is reconfirmed as a monophyletic lineage, and 4 major clades are recovered consistently (A-D of Weksler [2006]). Clades B, C, and D have a posterior probability greater than 0.95 ; however, clade A (containing Scolomys and Zygodontomys) has a lower posterior probability (0.61). The topological base of the Oryzomyini is unchanged from previous analyses, with clade C (Microryzomys, Oreoryzomys, Neacomys, and Oligoryzomys) as sister group to clade D (Eremoryzomys, Drymoreomys, Cerradomys, Sooretamys, Lundomys, Holochilus, Pseudoryzomys, Oryzomys, Nectomys, Amphinectomys, Aegialomys, Nesoryzomys, Melanomys, Sigmodontomys, Megalomys, and aphrastus), whereas clade B (Nephelomys, Oecomys, Hylaeamys, Handleyomys, Transandinomys, Euryoryzomys, and Mindomys) is basal to C and D. All these deep relationships receive nodal support $>0.95$. Relationships of taxa within clade B are still poorly supported, but all intergeneric relationships in clade $\mathrm{C}$ and most within clade $\mathrm{D}$ have high nodal support. "Sigmodontomys" aphrastus is found as sister to Megalomys but with a low posterior probability (0.71), a result similar to that provided by the parsimony analysis of Turvey et al. (2010). As in the analyses of Hanson and Bradley (2008), Sigmodontomys alfari is recovered within the Melanomys clade, with a moderate posterior probability of 0.87 . The 2 clades $S$. alfari + Melanomys and "S." aphrastus + Megalomys are in turn sister groups (0.88), in contrast to Turvey et al. (2010), who placed the aphrastus + Megalomys clade as sister to a clade containing Nectomys and Amphinectomys.

The maximum-likelihood analysis of the combined molecular partitions (IRBP, Cytb, and 12S) recovered a tree (Fig. 2) similar to the total evidence Bayesian tree, except for the nonrecovery of clade A; Scolomys is placed as the most basal of the Oryzomyini, but support for this area of the tree is low. The estimated model parameters are: (values for IRBP/12S/Cytb): $\mathrm{r}(\mathrm{A} \leftrightarrow \mathrm{C}): 1.15 / 2.67 / 13.6, \mathrm{r}(\mathrm{A} \leftrightarrow \mathrm{G}): 5.04 / 18.1 / 29.8, \mathrm{r}(\mathrm{A} \leftrightarrow \mathrm{T}):$ 0.597/7.27/12.8, $\mathrm{r}(\mathrm{C} \leftrightarrow \mathrm{G}): 0.475 / 0.745 / 1.1, \mathrm{r}(\mathrm{C} \leftrightarrow \mathrm{T}): 5.91 / 46.0 /$ 93.8, $\mathrm{r}(\mathrm{G} \leftrightarrow \mathrm{T}): 1 / 1 / 1$; freq: pi(A): 0.218/0.350/0.308, pi(C): 0.278/0.201/0.277, pi(G): 0.288/0.184/0.122, pi(T): $0.216 /$ $0.265 / 0.292$; alpha: $0.402 / 0.188 / 0.287$. The tree likelihood is 


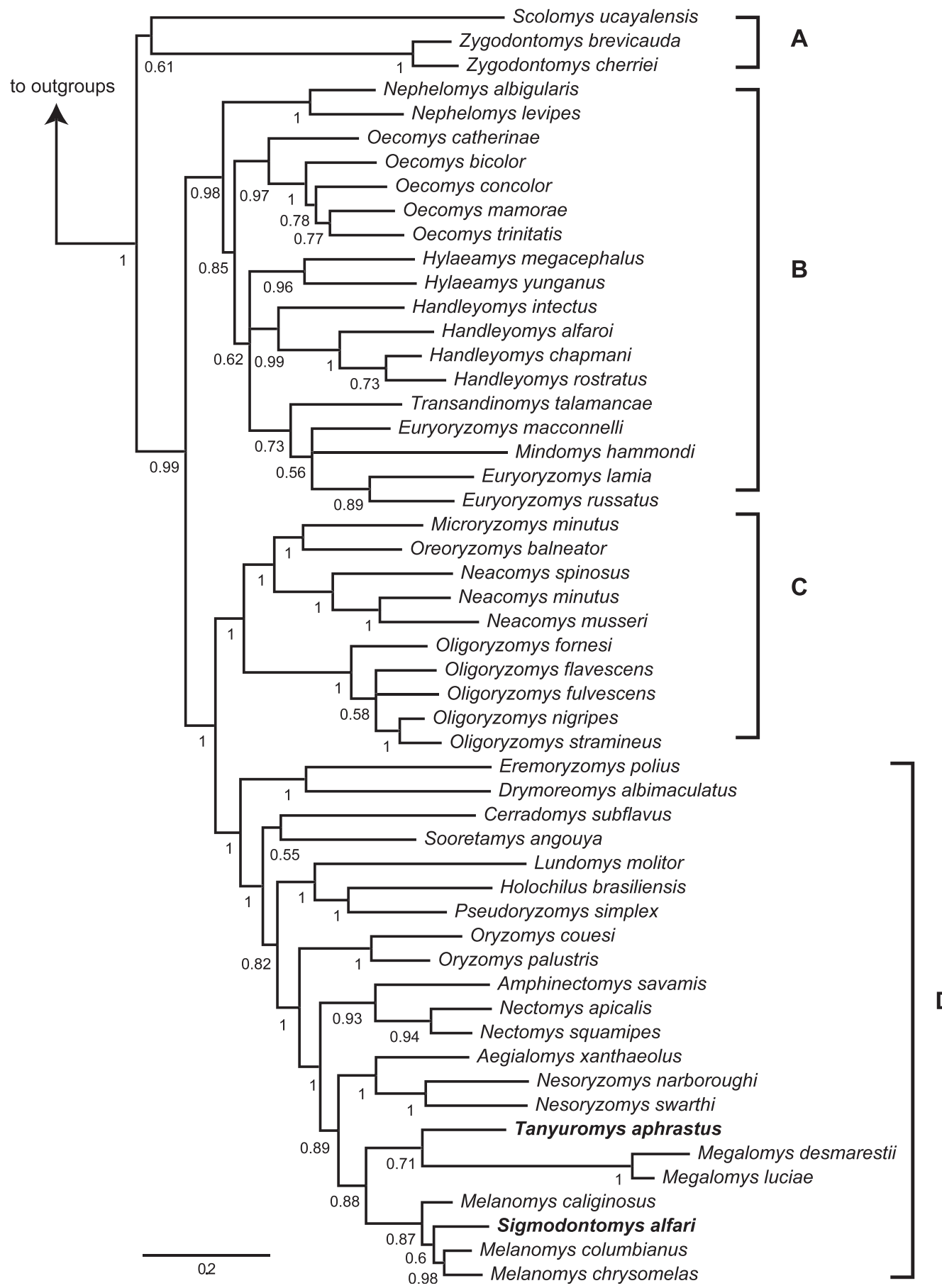

Fig. 1.-Phylogenetic relationships of Oryzomyini, based on Bayesian analysis of nuclear (interphotoreceptor retinoid-binding protein), mitochondrial (12S and cytochrome- $b$ ), and morphological characters. Numbers below branches represent posterior probabilities. Outgroups include Delomys sublineatus, Nyctomys sumichrasti, Peromyscus maniculatus, Rhipidomys nitela, Thomasomys baeops, and Wiedomys pyrrhorhinos. Clades referred to as A, B, C, and D are the same as those designated by those letters by Weksler (2006).

(-Ln): 26,929.81. The maximum-likelihood tree also differs in details of intergeneric relationships, usually involving nodes with low values. An exception is the change in position between the Oryzomys and the Nectomys + Amphinectomys lineages with respect to the clade including Melanomys, Sigmodontomys alfari, 'S.' aphrastus, Aegialomys, and Nesoryzomys (termed the Sigmodontomys clade). Identical results also are found in the parsimony and Bayesian analyses of molecular data only, indicating strong morphological signal placing Nectomys + Amphinectomys close to the Sigmodontomys clade. "Sigmodontomys" aphrastus is recovered as sister group to Sigmodontomys alfari + Melanomys with low bootstrap support $(62 \%)$.

Parsimony analysis of the total supermatrix resulted in 1 tree $(6,272$ steps, consistency index $[\mathrm{CI}]=0.23$, retention index $[\mathrm{RI}]=0.42$; Fig. 3 ), which has significant changes from 


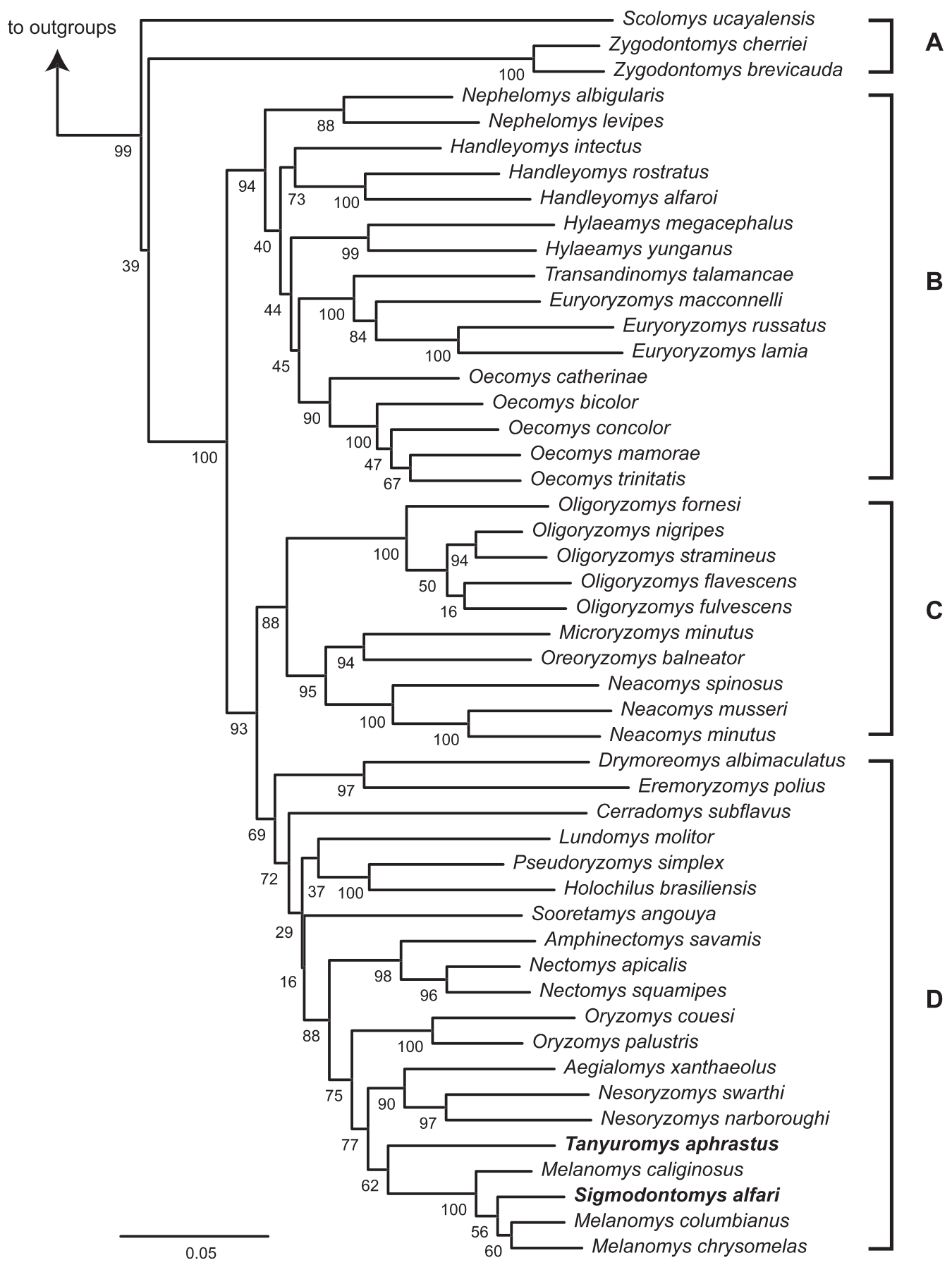

FIG. 2.-Phylogenetic relationships of Oryzomyini, based on the maximum-likelihood analysis of combined molecular (interphotoreceptor retinoid-binding protein + cytochrome- $b+12 S$ ) data sets. See Fig. 1 caption for outgroup taxa used in the analysis. Numbers below branches represent maximum-likelihood bootstrap values. Clades referred to as A, B, C, and D are the same as those designated by those letters by Weksler (2006).

the basal structure of trees recovered in previous cladistic analyses of the tribe (Percequillo et al. 2011; Turvey et al. 2010; Voss and Weksler 2009; Weksler 2003, 2006). Two of the main clades (C and D) are not monophyletic; Oligoryzomys does not cluster with Oreoryzomys, Microryzomys, and Neacomys, and Eremoryzomys and Drymoreomys are not recovered within clade $\mathrm{D}$. This novel structure of relationships is probably due to the phylogenetic signal saturation of mitochondrial genes (Cytb and 12s) in higher-level relationships within Oryzomyini in the parsimony analysis (Weksler 2003), which does not correct for multiple substitutions. In addition, the basal structure of the Oryzomyini in the parsimony analysis has weak nodal support, with all nodes receiving jackknife below 50\% (except Oryzomyini proper, with $90 \%$; Oryzomyini minus clade A, with 64\%; and clade B, with 61\%). "Sigmodontomys" aphrastus is recovered well 


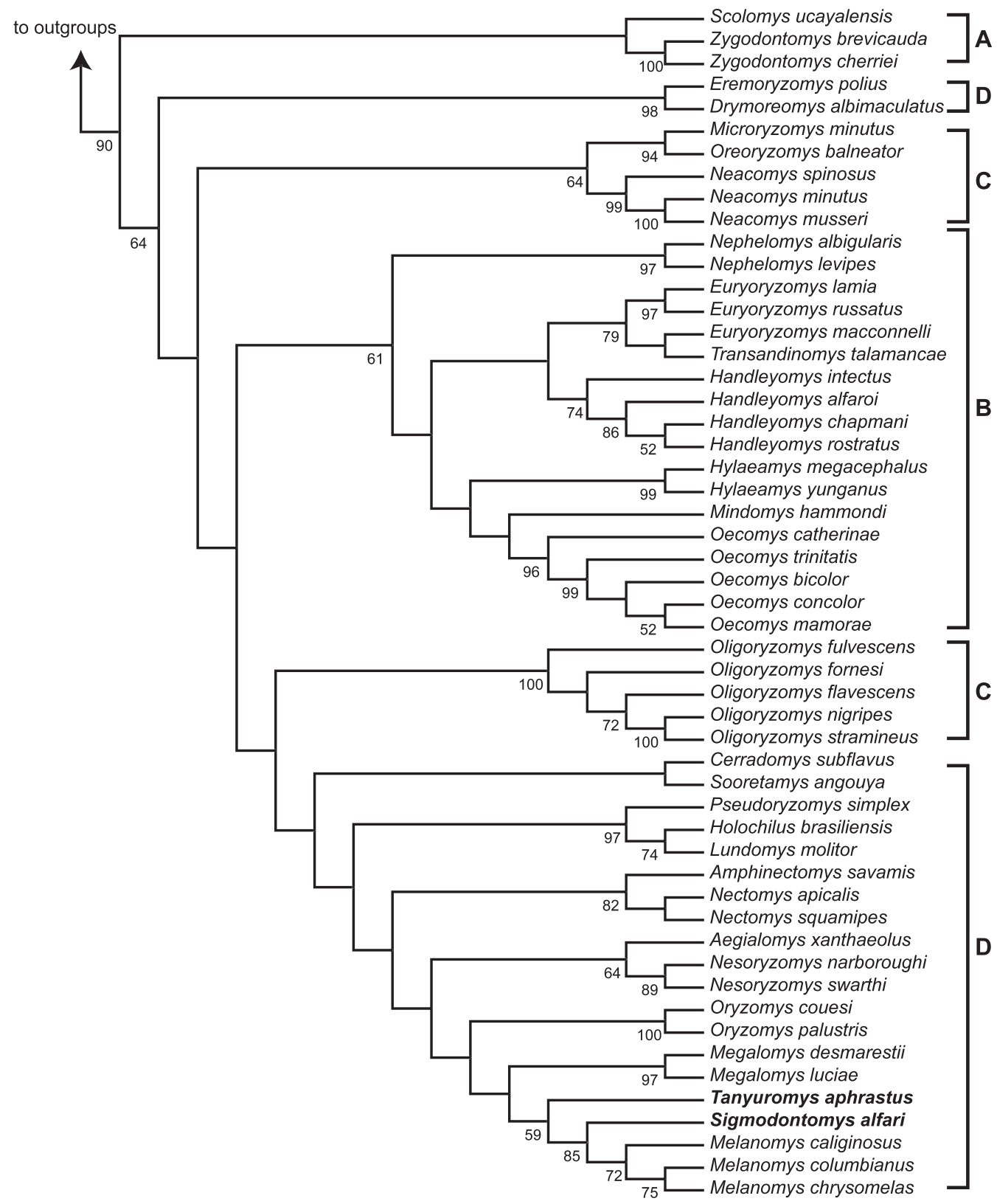

Fig. 3.-Phylogenetic relationships of Oryzomyini, based on maximum-parsimony analysis of morphological, nuclear (interphotoreceptor retinoid-binding protein), and mitochondrial $(12 \mathrm{~S}$ and cytochrome- $b$ ) gene characters (length $=6272$, consistency index $=0.23$, retention index $=0.42)$. Jackknife $(\geq 50 \%)$ nodal support indexes are shown below branches. Clades referred to as A, B, C, and D are the same as those designated by those letters by Weksler (2006); however, C and D are not monophyletic.

nested in clade D as sister taxon of the Sigmodontomys alfari + Melanomys clade but with support of only 59\%; jackknife support value for the latter clade is $85 \%$. Megalomys is in turn placed as the sister taxon to the clade that includes "Sigmodontomys" aphrastus but with jackknife $<50 \%$. Melanomys is recovered as monophyletic in the parsimony analysis, with a moderate jackknife value of $72 \%$.

Independent analyses of each data partition produced different hypotheses for the placement of 'S.', aphrastus and $S$. alfari (Fig. 4). In the morphology-only parsimony analysis (14 trees; 554 steps, $\mathrm{CI}=0.24$, RI $=0.63$; Fig. 4A), alfari and aphrastus are recovered as sister taxa (jackknife $=$
$52 \%)$, with Nectomys as their sister group ( $<50 \%)$; Melanomys is recovered as monophyletic with strong nodal support (98\%). Analyses of IRBP sequences (Fig. 4B) recovered aphrastus as sister group to the clade containing Melanomys, Sigmodontomys, Aegialomys, and Nesoryzomys (parsimony jackknife $<50 \%$, likelihood bootstrap $=50 \%$, Bayesian posterior $=0.79$ ) within clade D; Melanomys is not recovered as monophyletic, with Sigmodontomys as sister group to the clade Melanomys chrysomelas (J. A. Allen, 1897) $+M$. columbianus (J. A. Allen, 1899); other overall inferred relationships of Oryzomyini are identical to those of previous IRBP-only analyses (Weksler 2003, 2006). Analyses of Cytb 
A

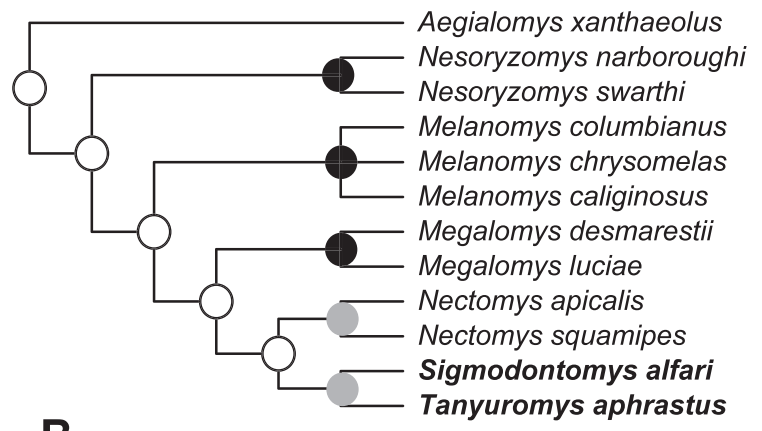

B

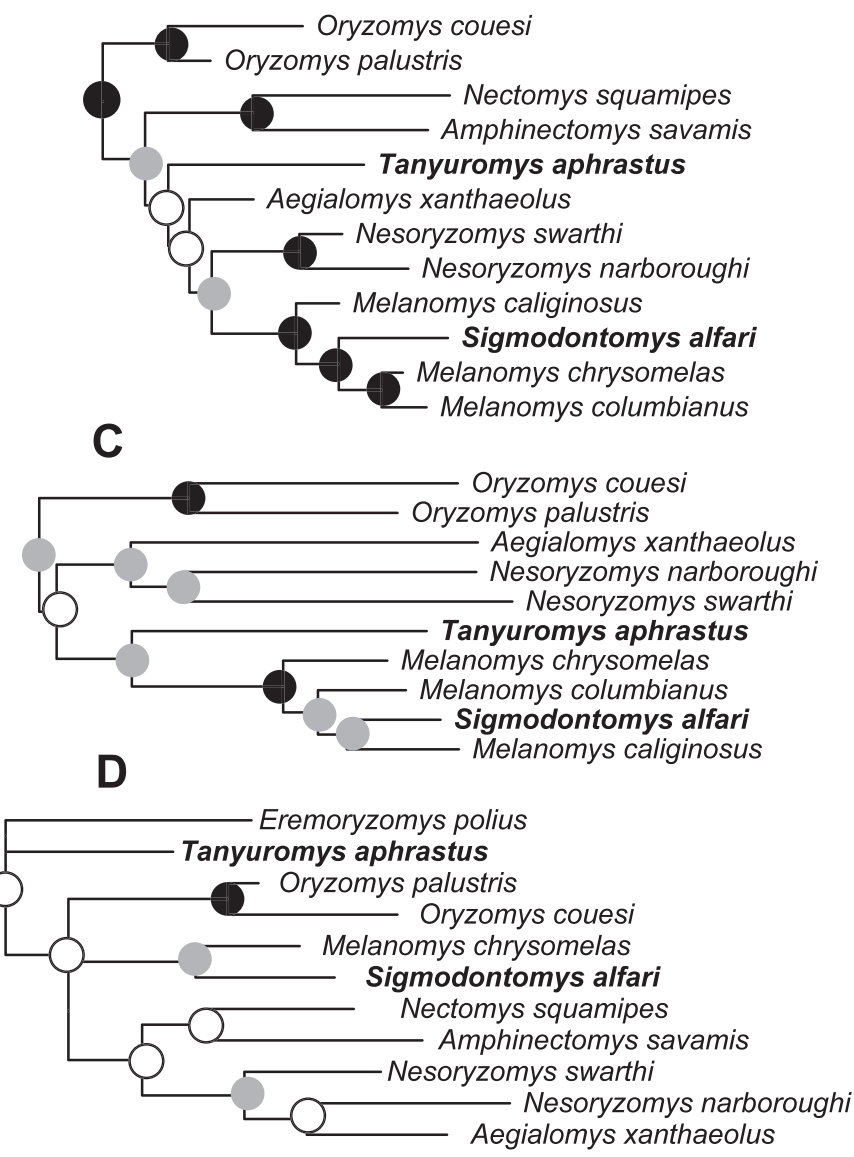

FIG. 4.--Relationships among Tanyuromys, Sigmodontomys, Melanomys, and related genera, in the partitioned analyses. Subtrees containing members of clade D phylogenetically close to the Sigmodontomys clade as recovered in the A) parsimony analysis of morphological characters, and maximum-likelihood analyses of B) interphotoreceptor retinoid-binding protein, C) cytochrome- $b$, and D) $12 \mathrm{~S}$ data sets. Circles at each node represent summaries of support values as recovered in cladistic parsimony (CP), maximum-likelihood (ML), and Bayesian inference (BI) analyses (parsimony only for the morphological data sets); black circles are nodes with maximumlikelihood bootstrap and cladistic parsimony jackknife $>85 \%$, and Bayesian inference posterior probability $=1$; gray circles are nodes with maximum-likelihood bootstrap and cladistic parsimony jackknife between $50 \%$ and $85 \%$, and Bayesian inference posterior probability between 0.95 and 0.99 ; and white circles are nodes with maximum-likelihood bootstrap and cladistic parsimony jackknife below 50\%, and Bayesian inference posterior probability below 0.95 . sequences (Fig. 4C) place aphrastus as sister taxon of the Sigmodontomys alfari + Melanomys clade (parsimony jackknife $=53 \%$, likelihood bootstrap $=76 \%$, posterior probability $=$ 0.94); Melanomys is again not monophyletic, but in this case $S$. alfari is found as sister group to $M$. caliginosus. Analyses of $12 \mathrm{~S}$ sequences (Fig. 4D) recover ' $S$.' aphrastus as a member of a polytomy including Eremoryzomys, and the clade containing Oryzomys, Sigmodontomys alfari, Melanomys, Nectomys, Amphinectomys, Aegialomys, and Nesoryzomys with low support; only 1 sequence is available for Melanomys, which is found as sister group to $S$. alfari.

These results corroborate earlier studies (Percequillo et al. 2011; Turvey et al. 2010; Weksler 2006), reconfirming that there is no sister relationship between aphrastus and Mindomys hammondi. The Sigmodontomys-Melanomys clade does contain aphrastus; however, aphrastus and alfari are paraphyletic with respect to Melanomys. Thus, far from being a dubiously distinct species of Oryzomys, as Hall (1981) implied, or a species of Sigmodontomys, as it has generally been regarded to be by authors since Musser and Carleton (1993) provisionally treated it as such, aphrastus represents a new genus in the Oryzomyini (as defined by Weksler et al. 2006), which may be characterized as follows.

\section{Tanyuromys, new genus \\ Long-tailed Montane Rats}

Figs. 5-7

Oryzomys: Harris, 1932:5; part; not Oryzomys Baird, 1857.

Sigmodontomys: Musser and Carleton, 1993:748; part; not Sigmodontomys J. A. Allen, 1897.

Type species.-Oryzomys aphrastus Harris, 1932.

Included species. - The type species.

Known distribution of genus.-Discontinuously at middle elevations from north-central Costa Rica to northwestern Ecuador (Fig. 8).

Etymology.-Long-tailed mouse, from the Greek tany (long), oura (tail), and mys (mouse).

Diagnosis.-Oryzomyini with exceptionally long tail with terminal tuft; bony palate short; shallow zygomatic notches; jugal large; stapedial foramen and posterior opening of alisphenoid canal small; squamosal-alisphenoid groove and sphenofrontal foramen absent; molars uniquely complex and lophodont for extant Oryzomyini, with complicated enamel folding pattern of flexi and flexids (Fig. 6). Stomach unilocular-hemiglandular, glandular epithelium extending into corpus; gall bladder absent.

Description.-Oryzomyini with body pelage very long, thick, and soft; slate gray basally (approximately $85 \%$ of length), tipped with tawny dorsally, more buffy laterally. Mystacial and superciliary vibrissae dark and very long, extending posteriorly beyond posterior margins of pinnae when laid back. Guard hairs on rump up to at least $18 \mathrm{~mm}$ in length. Dorsoventral countershading distinct but less so than in many related forms. Fur ventrally less dense than dorsally and a paler gray (plumbeous) liberally washed with buff, described 


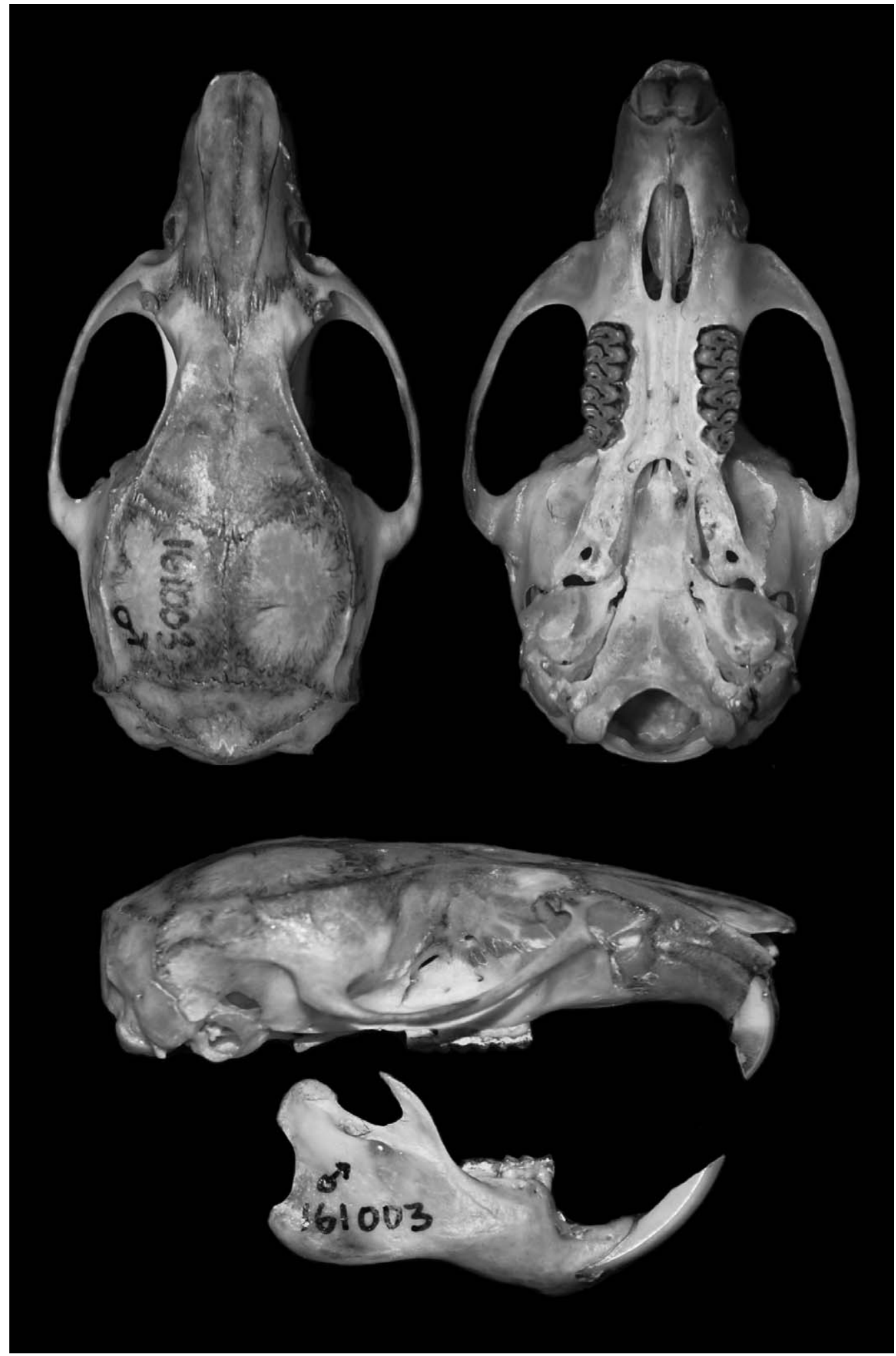

FIG. 5. - Skull of adult Tanyuromys aphrastus (KU 161003, male). Greatest length of skull = $33.0 \mathrm{~mm}$.

as “buffy ochre" by Reid (1997:208, 2009:212). Juvenile pelage, based on the Panamanian subadult (USNM 541201), markedly different from that of adults (and from that of the even younger Costa Rican subadult, which has more adultlike pelage), being softer, fluffier, and woolly; pale plumbeous, lightly tipped with drab above (overall closest to Hair Brown), more heavily tipped with dull buff below, and small pencil at tip of tail black.

Pinna small, not reaching eye when laid forward, sparsely to moderately covered with short, blackish, dark brown, or 


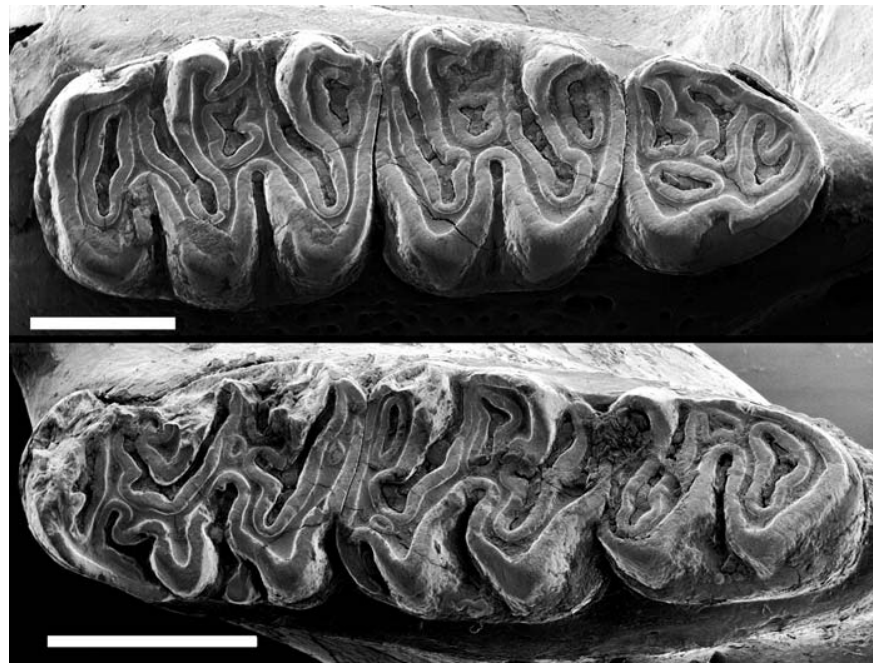

Fig. 6.-Molar toothrows of Tanyuromys aphrastus (UMMZ 155808). Top) upper left toothrow; bottom) lower left toothrow. Bars represent $1 \mathrm{~mm}$. Anterior is to the left.

reddish brown hairs, both internally and externally. Manual claws small and unkeeled. Hind foot long and slender, adapted for terrestrial life, its skin pale brown; sparsely to moderately covered with short, pale brown to dark brown hairs dorsally; digits 2, 3, and 4 long and subequal in length, with 3 the longest; claws sharp and strongly curved, sometimes with reddish pigmentation at tips; claw of digit 1 extending just beyond base of phalanx 1 of digit 2; claw of digit 5 extending beyond middle of phalanx 2 of digit 4 . Pes without natatory fringes. Bristles at base of hind claws variable in length and density, but usually with a moderate number of pale brown to darker brown bristles reaching or almost reaching the tips of the claws. Small, dark squamae visible to naked eye on hind foot both dorsally and ventrally, distinct and dense plantar squamae distal to thenar pad (absent on heel). Hind foot with 4 large and fleshy interdigital pads, with interdigitals 2 and 3 set apart from 1 and 4 as pairs; a thenar pad; and a hypothenar pad absent, vestigial, or moderately well developed. Tail exceptionally long and slender, usually more than 1.5 times length of head plus body; sparsely haired (appearing superficially nearly naked) with short, stout, black or brown hairs, 3 per scale; overall basically brown or blackish concolor or with slight bicoloration except proximally. Small scales arranged in an annular fashion $(\sim 14$ rows/cm just past outstretched feet in 1 adult specimen) and, because of overlap, exposed portions hexagonal; tail with small terminal tuft. Four pairs of mammae: pectoral, postaxial, abdominal, and inguinal.

Skull (Fig. 5) moderately robust, with profile little arched (essentially flat) from the tips of the nasals to the frontoparietal sutures. Rostrum short, stout, and flanked by very shallow, rounded zygomatic notches; interorbital region anteriorly convergent with strongly beaded supraorbital margins. Braincase broad and slightly inflated, confluent with well-developed and flared temporal crests; lambdoidal and nuchal crests developed in older adults. Large interparietal anteriorly truncated, obtusely angled posteriorly, and with lateral

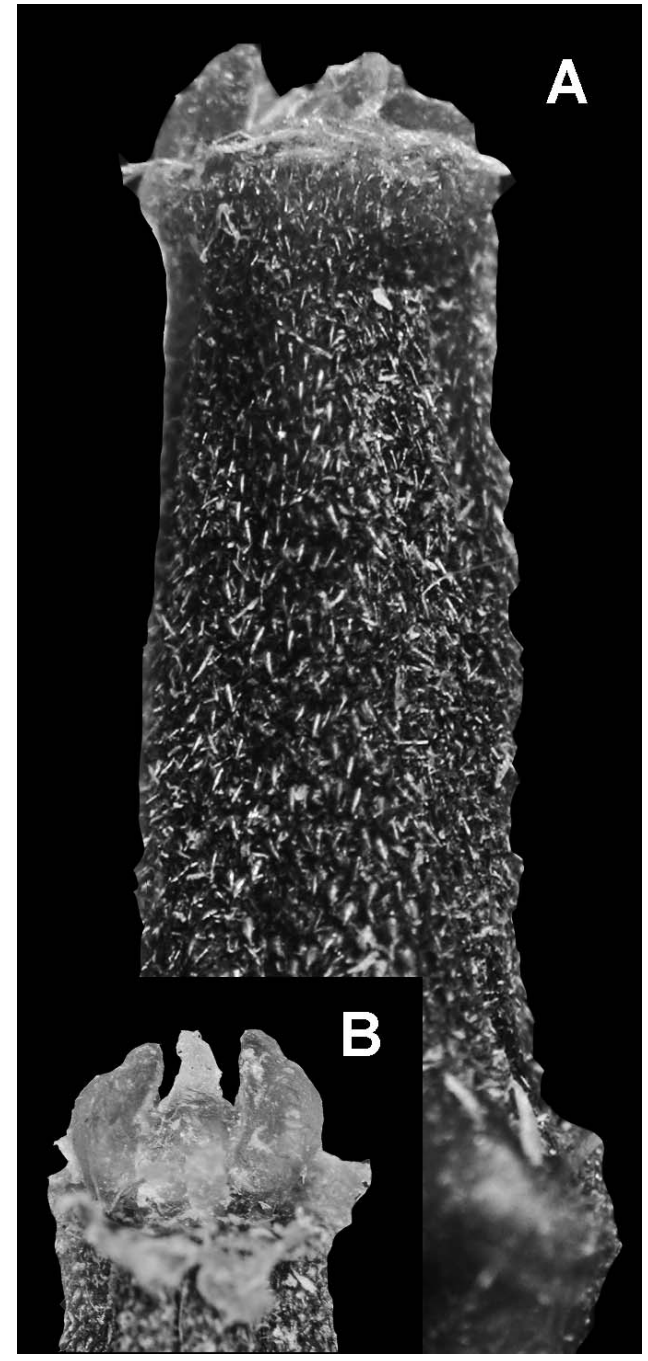

FIG. 7.-Glans penis of Tanyuromys aphrastus (KU 161003). A) Dorsal view of phallus, showing reduced terminal apparatus and epidermal spines covering entire shaft. B) Ventral view of terminal apparatus, showing the 2 lateral mounds with short digits and the central mound with a reduced cartilaginous component.

extensions. Zygomatic plate of medium width, its anterior edge ranging from slightly convex along its dorsal half to slightly convex along its entire length, its posterior margin anterior to alveolus of M1; anterior margin straight, without anterodorsal spinous process. Zygomatic arches convergent anteriorly, relatively unbowed, widest at squamosal root; jugal present and large (the maxillary and squamosal zygomatic processes widely separated, not overlapping in lateral view). Nasals with acutely angled posterior margins; extending posteriorly beyond premaxillae and behind lacrimals, nearly reaching interorbital constriction. Lacrimals usually with longer maxillary than frontal sutures. Posterior wall of orbit smooth. Frontosquamosal suture anterior to frontoparietal suture (dorsal facet of frontal in broad contact with squamosal). Parietal with broad lateral expansion, a large portion dipping below the temporal ridge posteriorly. Basicranial flexion weakly pronounced, foramen magnum oriented mostly caudad. Incisive foramen short and narrow, not extending posteriorly to level of alveolus of M1, 


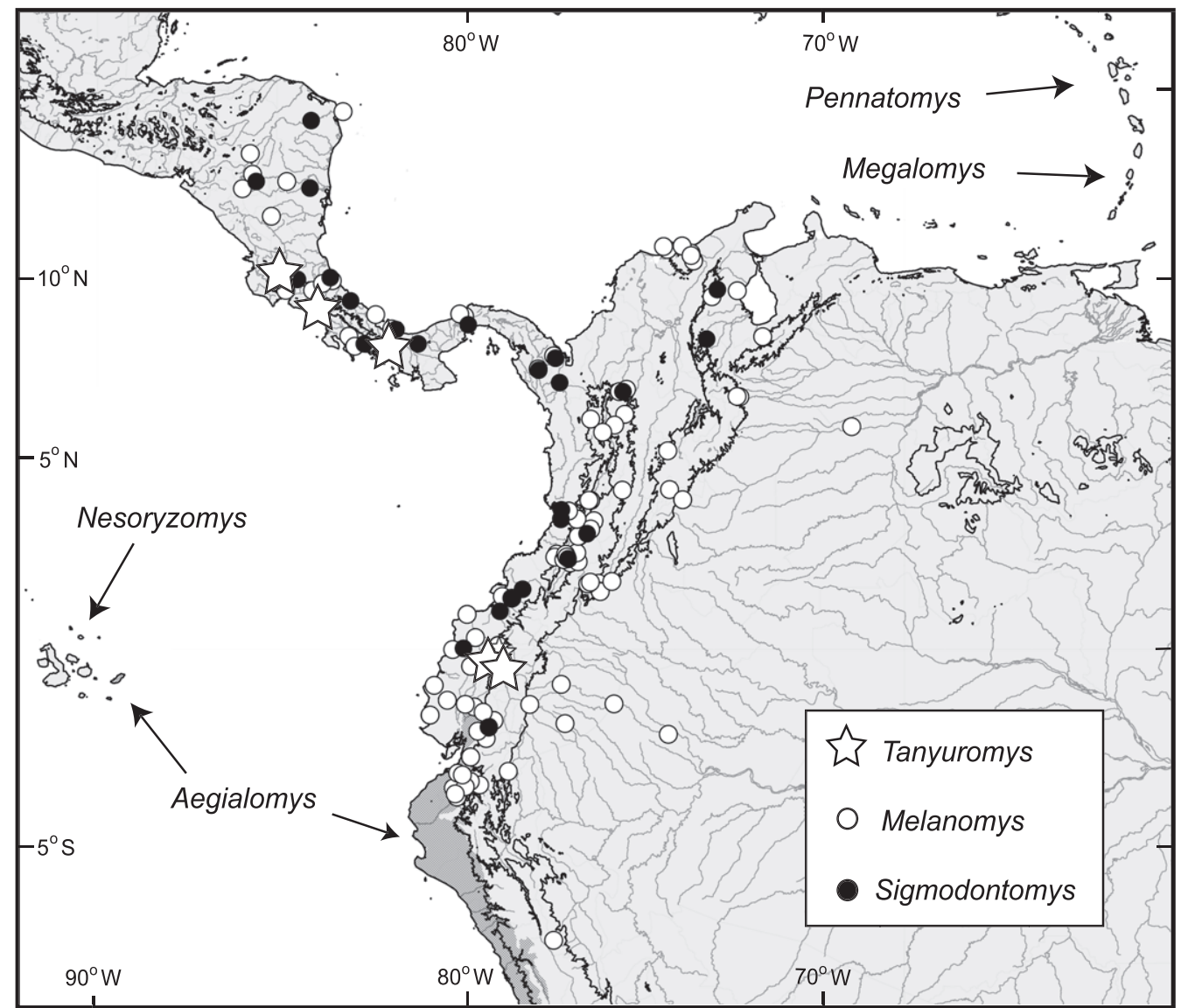

Fig. 8.-Map of northwestern South America, Central America, the Windward and Leeward Islands, and the Galapagos, showing the distribution of the genera of Oryzomyini discussed in the text. All known localities of Tanyuromys are plotted (open stars) as are representative localities for the other mainland taxa of the trans-Andean clade-Melanomys (open circle) and Sigmodontomys (closed circle)—using locality data from museum records (Appendix I). Arrows indicate the distributions of other members and a putative member (Pennatomys) of this clade-Megalomys and Pennatomys (both extinct) in the Caribbean islands and Nesoryzomys and Aegialomys in the eastern Galapagos. Aegialomys also occurs in mainland western Ecuador and Peru (shaded areas).

widest at midlength and tapering symmetrically anteriorly and posteriorly. Bony palate relatively short as compared with other Oryzomyini, extending just beyond M3s and smooth or weakly sculpted between molar rows. Posterolateral palatal pits simple and small and level with the palatine; mesopterygoid fossa penetrating anteriorly between maxillae; bony roof of mesopterygoid fossa usually perforated by narrow sphenopalatine vacuities (a juvenile specimen has a completely ossified mesopterygoid roof). Alisphenoid strut absent (buccinatormasticatory foramen and accessory foramen ovale confluent); alisphenoid canal with large anterior opening. Stapedial foramen and posterior opening of alisphenoid canal small; squamosal-alisphenoid groove and sphenofrontal foramen absent; secondary anastomosis of internal carotid crosses dorsal surface of pterygoid plate ( = carotid circulatory pattern 3 of Voss [1988]). Posterior suspensory process of squamosal absent. Postglenoid foramen large and rounded; subsquamosal fenestra vestigial or absent. Auditory bulla small. Periotic exposed posteromedially between ectotympanic and basioccipital, but usually not extending anteriorly to carotid canal; mastoid unfenestrated and lacerate foramina group absent. Coronoid process long, slender, pointed, posteriorly angled dorsally, and reaching level of rounded condyloid process. Capsular process of lower incisor alveolus absent or present as a slight, rounded elevation not protruding above level of coronoid-condylar notch, the variable condition of the capsular projection seems to be unrelated to age variation; superior and inferior masseteric ridges conjoined anteriorly as single crest below $\mathrm{m} 1$.

Upper incisors ungrooved, slightly opisthodont (Fig. 5), with smoothly rounded enamel bands. Maxillary toothrows straight to slightly bowed outward; when straight, nearly parallel, converging slightly anteriorly. Molars (Fig. 6) large, pentalophodont, and bunodont, with complicated occlusal patterns having extensive, deep, steep-sided flexi and fosseti (enamel islands) with irregular and jagged borders. Anteromedian flexus absent. Lophs and lophids quickly wearing to planar surfaces extending across lingual cones and labial conids; mesolophs on upper molars. Labial and lingual flexi of M1 and M2 deeply interpenetrating; labial flexi convoluted (wrinkled) and enclosed by a cingulum. M1 broadly rectangular, with accessory labial root; anterocone not divided into labial and lingual conules; anteroloph well developed and fused with anterostyle on labial cingulum, fused with anterocone (anteroflexus 
reduced or absent). Protostyle absent; paracone usually connected by enamel bridge to posterior moiety of protocone; median mure connected to protocone. Mesoloph well developed, and paralophule forming connection between paracone and mesoloph, isolating lingual portion of mesoflexus into a mesofossette. M2 broad, complex, subcircular; protoflexus absent; mesoflexus present as single internal fossette (a 2nd very small labial fossette is present in the adult from Panama); paracone without accessory loph. M3 broadly triangular or round. M3 smaller than M2, with posteroloph and diminutive hypoflexus that tends to be eliminated through wear. All lower molars (Fig. 6) with anterolabial cingulum and small anterolophid that disappears with wear. Anteroconid of $\mathrm{m} 1$ without anteromedian flexid, but with accessory lingual and labial roots. Ectolophid absent on $\mathrm{m} 1$ and $\mathrm{m} 2$, but mesolophid present and distinct. Posteroflexid present on rectangular m3. (All shapes given of teeth are those of their appearance in occlusal view.)

The adult male from Costa Rica (KU 161003) has the glans penis covered with epidermal spines (Fig. 7). Distal bacular cartilage small and trifid (with a short and slender central digit), bacular mounds not concealed by nonspinous tissue on rim of terminal crater, dorsal papilla spineless, and urethral processes without subapical lobules. Stomach unilocularhemiglandular, glandular epithelium extending into corpus. Gall bladder absent.

Comparisons.-Tanyuromys differs from all other extant Oryzomyini (sensu Weksler 2003; Weksler and Percequillo 2011; Weksler et al. 2006) in the degree of lophodonty and complication of the enamel folding pattern of flexi and flexids on the molars (Fig. 6). More specifically, Tanyuromys differs from Neacomys and Scolomys in having soft, rather than spiny, fur. All known species of Neacomys and Scolomys are considerably smaller than the known species of Tanyuromys. From Oryzomys (sensu lato), Oligoryzomys, Melanomys, Microryzomys, Nesoryzomys, Oecomys, and the extinct Megalomys, Tanyuromys is best distinguished on the basis of dental characters. Tanyuromys agrees with Nectomys and Sigmodontomys in having long nasals; more or less evenly rearwardly diverging, beaded, supraorbital and postorbital shelves; rearwardly diverging zygomata; less elongate, evenly bowed incisive foramina; pitted palate with longitudinal channels; broad, U-shaped mesopterygoid fossa; absence of posterior subsquamosal foramina; small auditory bullae; large molars; small ears; and a distinctive, grayish juvenile pelage. With Nectomys (but not Sigmodontomys), Tanyuromys agrees in having long fur, long secondary folds on the upper molars, and overlapping primary folds. Tanyuromys differs from both Nectomys and Sigmodontomys in having much more complex molar patterns, less-hypsodont molars, a short rostrum; much smaller zygomatic notch; much less-developed temporal ridges; a broad, inflated braincase; and a proportionally longer tail.

Tanyuromys has consistently been recovered in a 3-member clade with Sigmodontomys and Melanomys, and so comparisons among the 3 genera are especially pertinent. The pelage of Tanyuromys is somewhat longer and softer than in Sigmodontomys and the vibrissae are much longer, extending posteriorly beyond the pinnae. Tail length in Tanyuromys usually exceeds 1.5 times the length of the head plus body and there is a terminal tuft, whereas in Sigmodontomys, the tail is about the same length as the head plus body and there is no tuft. The hexagonal-appearing caudal scales of Tanyuromys are smaller than those in Sigmodontomys. Both Tanyuromys and Sigmodontomys have a small auditory bulla, definite postorbital ridge, subsquamosal fenestra, derived carotid arterial circulation, and well-developed supraorbital crests. Tanyuromys has a less-robust but relatively broader skull with a more-inflated braincase than does Sigmodontomys. In Tanyuromys, the zygomata are more curvilinear and there is less supraorbital beading than in Sigmodontomys. Tanyuromys has a well-developed jugal, but it is reduced or absent in Sigmodontomys. Supraorbital beading in Tanyuromys extends dorsally, whereas in Sigmodontomys the beading tends to overhang the orbits. Sigmodontomys has a broader zygomatic plate than does Tanyuromys, and it forms a deeper notch. The temporal ridges are less developed than in Sigmodontomys. The nasals taper posteriad manifestly in Tanyuromys, whereas their margins are subparallel in Sigmodontomys. In Tanyuromys, the bony palate is shorter, both absolutely and relatively, reaching the level of posterior edges of M3s only in old animals; whereas in Sigmodontomys the palate extends clearly beyond the M3s. The system of palatal pits is more complex in Sigmodontomys than in Tanyuromys. The capsular processes are much less developed in Tanyuromys than in Sigmodontomys. Dentally, Tanyuromys resembles Sigmodontomys. Both have large, complex molars with 4 roots on M1 and 3 on $\mathrm{m} 1$. Some of the more noteworthy differences are that in littleworn molars of Tanyuromys there are multiple irregularshaped fissures representing a complicated anteroflexus (or the anterior internal fold of Hershkovitz [1962]) in the 1st upper molar; the paraflexus is undulating instead of being smoothly curved; and the mesostyle is better developed. In the 1st lower molar, there are multiple fissures derived from the protoflexid and anteroflexid. Overall, the fissures are more extensive and more branching, "dissecting" the teeth in a "gnarled branch", pattern. In general, the upper molars are more lophodont in Tanyuromys than in Sigmodontomys. Tanyuromys possesses an M3 larger, in comparison with the size of the M2, than does Sigmodontomys, although, in both, the M2 is larger than the M3. Tanyuromys possess an anterolabial cingulum on $\mathrm{m} 2$ that is missing in Sigmodontomys.

Tanyuromys differs from Melanomys by its much longer tail, both relatively and absolutely, with terminal tuft. The 2 have different fur color patterns: Tanyuromys has medium brown pelage with buffy highlights, whereas the fur in Melanomys is very dark brown dorsally and has a less contrastingly pale venter. Tanyuromys has much longer vibrissae, extending posteriorly beyond the pinnae. Melanomys has an obvious hypothenar pad on the hind foot, whereas it is sometimes absent or vestigial in Tanyuromys. The nasal bones of Tanyuromys taper acutely posteriorly, whereas in Melanomys they terminate bluntly. In Melanomys, the zygomatic plate is broader and forms a deeper notch. The jugal in Tanyuromys is manifestly 
developed, but is reduced or absent in Melanomys. Tanyuromys also has more opisthodont incisors and lophodont upper molars (the labial and lingual flexi do not interpenetrate deeply on the upper molars of Melanomys). The paracone and protocone are connected by the median moiety in Melanomys but have a posterior connection in Tanyuromys.

Because Mindomys occurs sympatrically with Tanyuromys, they were previously considered closely related, and their skulls and dentition are superficially similar in appearance, it is useful to contrast the 2. The skull of Mindomys has both the rostrum and the braincase more elongate than in Tanyuromys, and the interorbital region narrows anteriorly less abruptly. The cranial profile is essentially flat in Tanyuromys, from tips of nasals to frontoparietal sutures, but somewhat arched in Mindomys. The nasals reach past the lacrimals in Tanyuromys, but not in Mindomys. The anteriormost portion of the posterior edge of the zygomatic plate in Tanyuromys is anterior to M1 but is at the level of anterior edge of M1 in Mindomys. Zygomatic arches are more convergent anteriorly in Tanyuromys than in Mindomys. In Mindomys, the incisive foramina are relatively broad and teardrop-shaped and are widest threefourths of the distance posteriad, whereas in Tanyuromys they are more elongate and more evenly bowed. In Mindomys, the carotid circulation is pattern 1 (squamosal-alisphenoid groove and sphenofrontal foramen present) of Voss (1988), whereas in Tanyuromys, it is pattern 3 (squamosal-alisphenoid groove and sphenofrontal foramen absent, secondary anastomosis of internal carotid crosses dorsal surface of pterygoid plate). Postglenoid foramen is large and rounded in Tanyuromys; small and compressed dorsoventrally in Mindomys. Superior and inferior masseteric ridges join below $\mathrm{m} 1$ to form a single ridge in Tanyuromys; in Mindomys, they converge anteriorly to form an open chevron below m1. The labial flexi of M1 and M2 in Tanyuromys have irregular, convoluted borders, whereas this is not the case in Mindomys. In Tanyuromys, the anteroloph of M1 is fused with the anterocone, an anteroflexus being reduced or absent. In Mindomys, the anteroloph is separated from the anterocone by an anteroflexus. In the M1 of Tanyuromys, the labial accessory root is present but it is absent in Mindomys. There is no ectolophid on $\mathrm{m} 1$ of Tanyuromys but there is in Mindomys. The $\mathrm{m} 1$ of Tanyuromys possesses accessory roots, whereas in Mindomys they are absent, there being merely 2 large roots, 1 fore and 1 aft. In Tanyuromys, glandular epithelium extends into the corpus of the stomach, whereas in Mindomys it does not.

Additional characters of the species Tanyuromys aphrastus and comparisons between that species and Melanomys, Mindomys hammondi, Nephelomys devius, and S. alfari, and a review of what little is known of the ecology of T. aphrastus were provided by McCain et al. (2007). Externally, Tanyuromys is similar in appearance to the sometimes sympatric Nephelomys, although apparently always having a somewhat longer and slightly tufted tail and smaller ears. The muzzle of Nephelomys is also more elongated. Collectors should be aware of this because we know of 2 instances in which Tanyuromys was mistaken in the field for Nephelomys.
Comments. - Cadena et al. (1998) reported a single specimen of a "Sigmodontomys sp." from Nariño in the Colombian Chocó, and suggested that it was morphologically close to M. hammondi and "Sigmodontomys" aphrastus. Our ongoing research suggests that the Nariño rat in fact belongs to a new taxon phylogenetically close to Mindomys hammondi, and is not a member of Sigmodontomys, Tanyuromys, the "'Sigmodontomys" clade, or even clade D of Weksler (2006).

\section{Discussion}

Ellerman (1941:361) was the 1st to compare Sigmodontomys alfari with Melanomys, which he did based on cusp patterns, stating that in Nectomys (in which he included Sigmodontomys as a subgenus) "[C]lear traces of the subsidiary ridges always present. The molars are more hypsodont than [in] Oryzomys, and are clearly distinct from the majority in pattern, though they may be approached by the subgenus Melanomys.' Hershkovitz (1944:73), also comparing S. alfari with Melanomys, wrote "There is a superficial resemblance between adults in old pelage and juveniles of alfari to adults and juveniles, respectively, of $O$. (Melanomys) caliginosus." Weksler (2003), using DNA sequence data, recovered a clade including Amphinectomys, Nectomys, Melanomys, Sigmodontomys, Nesoryzomys, Aegialomys xanthaeolus (Thomas, 1894), Oryzomys palustris (Harlan, 1837), and O. couesi (Alston, 1877) with Sigmodontomys alfari and Melanomys being sister groups; Tanyuromys aphrastus was not included due to lack of genetic material. Weksler (2006) was the 1st to publish a rationale for a proposed relationship of " $S$." aphrastus with any other taxon or taxa, based on a phylogenetic interpretation of morphological characters, despite the various generic assignments and statements as to affinity that had been made concerning aphrastus over the past 7 decades.

Our results also corroborate the findings of Hanson and Bradley (2008), which point to a nonmonophyletic status for Melanomys. We recovered Sigmodontomys alfari as nested within Melanomys, in the Bayesian analysis of all data and in the maximum-likelihood analysis of combined genetic data, as well as in the separate analyses of each IRBP and $C y t b$ data set. Melanomys is recovered as monophyletic in the parsimony analyses of the total data set, and of the morphological data taken in isolation. Nodal support for most of these results, however, is low. Inclusion of S. alfari within Melanomys has only 0.6 posterior probability in the total Bayesian analysis and $56 \%$ bootstrap in the maximum-likelihood analysis (nodal support for the clade including Melanomys and S. alfari, however, is extremely high, especially in the maximumlikelihood analysis of genetic data, with $100 \%$ bootstrap). On the other hand, monophyly of Melanomys in the parsimony analysis of morphological characters is high. The latter result is not surprising, because Melanomys is clearly one of the most distinctive groups of Oryzomyini (Weksler 2006), possessing several apomorphies, especially its volelike aspect: short tail, lack of countershading, dark pelage, and short pinnae. 
What could be causing the nonmonophyly of Melanomys in the molecular data set? The possibility of contamination can be discarded because sequences for Melanomys and Sigmodontomys alfari were generated in 2 different laboratories and using different specimens of Melanomys (Hanson and Bradley 2008; Weksler 2003). Because the recovered structure of each gene (Cytb and IRBP; Fig. 4) provides different results concerning the position of $S$. alfari within Melanomys, we suggest that this could be a case of nonconcordance between gene trees due to retention of ancestral polymorphisms in one of these genes.

Submerging aphrastus, S. alfari, and Melanomys into a single genus (along with Megalomys, as based on the combined analyses) would produce a taxonomic arrangement in accord with the recovered phylogenetic structure and could be a means of "simplifying" the classification. We think, however, that this option is counterindicated by the sharp morphological differentiation between members of these lineages and it would diminish the heuristic value of the classification in terms of communicating the differences. Melanomys is one of the few genera of Oryzomyini that has been recognized since the early 20th century, and is also one of the few such genera maintained continuously throughout the convoluted taxonomic history of the Sigmodontinae as a whole.

We document that Aegialomys, Nesoryzomys, Melanomys, Megalomys, Sigmodontomys, and Tanyuromys form a wellsupported, morphologically diverse, and largely trans-Andean clade within the broadly distributed tribe Oryzomyini. The members of this clade occupy (or have occupied) various ranges in southern Central America (especially the highlands and Caribbean versant), northern South America (especially west of the Andes), in the Galapagos, and, up to historic times, in the Lesser Antilles (Turvey et al. 2010). In addition, the "Megalomys" that occurred on Curaçao and became extinct in the Pleistocene may well have been a member of this clade but it has yet to be critically studied (McFarlane and Lundberg 2002). Members of the clade tend to be relatively large for cricetines and they occur in a variety of habitats. Their insular distributions attest to these animals being excellent dispersers across salt water.

Haffer (1987:123) wrote that the trans-Andean forest region "comprises the humid lowlands west and north of the Andes, i.e., the Pacific rain forests of Colombia and Ecuador, the humid portions of Caribbean Colombia, the humid middle Magdalena Valley and the forested lowlands of Middle America." Using this definition, Musser et al. (1998:174) discussed, at length, the trans-Andean distribution of what was then called Oryzomys bolivaris (now Transandinomys bolivaris (J. A. Allen, 1901)), including "Its geographic range in the trans-Andean region is closely tied to ever wet and humid tropical evergreen forests extending from coastal lowlands to midmontane elevations and is concordant with the distributions of other rodents tied to the same forest environments.' Other species that Musser et al. (1998) treated as having a trans-Andean distribution are Sigmodontomys alfari and "Sigmodontomys" aphrastus. They further stated that future revisionary studies may reveal a trans-Andean distribution for Melanomys caliginosus. Weksler (2003:345) also treated Sigmodontomys (encompassing both alfari and aphrastus) as trans-Andean in distribution.

Tanyuromys is the 1 genus in the clade recovered herein that is not primarily restricted to the lowlands; it occurs at middle and higher elevations in mountainous regions of Costa Rica, Panama, Colombia (presumably), and Ecuador. Melanomys occurs in a wide array of lowland and middle-elevation habitats, and is especially abundant in highly disturbed forests. Melanomys is broadly distributed in the Caribbean lowlands of Central America and ranges down (mostly) the Pacific lowlands of tropical South America, occurring up to 2,300 m, and may include as many as 6 species (Hanson and Bradley 2008). Sigmodontomys, with 1 recognized lowland species, also occurs in the Caribbean lowlands of southern Central America and into the Pacific lowlands of northern South America.

Nesoryzomys occurred on at least 6 Galapagos islands (Steadman and Zousmer 1988). Reaching the Galapagos constitutes the greatest overwater dispersal distance for terrestrial mammals. Aegialomys is known from a single extant species that occurred on 2 islands in the Galapagos and 1 or more extant species from the mainland's Pacific lowlands of Ecuador and Peru (where it also ranges up to about 2,500 m). Although Nesoryzomys and Aegialomys are not trans-Andean in the sense of typically being found in wet forests, they are transAndean in the purely spatial sense, being found west of the Andes on the mainland or the Galapagos, or both. Therefore, it seems that there must have been at least 2 invasions of the Galapagos by members of this clade-by an ancestor of present-day and extinct Nesoryzomys and (presumably more recently) by the present-day genus Aegialomys.

In Patton and Hafner's (1983:557) phenetic cluster analysis based both on distance and correlation matrices of 23 qualitative characters, Nesoryzomys was linked with the 2 species of Aegialomys, forming "a definite unit relative to other oryzomyines, not joining any of the latter until fairly far out in the dendrogram." Other phenograms based on using different methods and character states, however, gave different configurations and their factor analysis showed (p. 557) “... strong separation of Nesoryzomys from the other oryzomyines [including Aegialomys]." Nonetheless, on the basis of penis morphology and "the clustering pattern based on ... skin and skull characters which link Nesoryzomys with $O$. [Aegialomys] xantheolus [sic] and O. [Aegialomys] bauri $[=$ A. galapagoensis]," Patton and Hafner (1983:560) hypothesized that Nesoryzomys arose from a "xantheolus-like [sic] ancestral stock inhabiting the xeric coastal regions of Peru and Chile." Unaccountably, although Patton and Hafner (1983:560) gave Peru and Chile as having housed the ancestral stock, and the Galapagos, the entirety of Peru, and northernmost Chile are all in the tropics, they discounted the origins of any of the Galapagos rats "among tropical representatives of the oryzomyine complex."

The sister relationship between the mainland Aegialomys and the Galapagoan Nesoryzomys that was inferred by Patton 
and Hafner (1983) and that we have consistently found is quite remarkable and intriguing. Both Aegialomys and Nesoryzomys occur on the Galapagos, an island group some $970 \mathrm{~km}$ west of the South American mainland. Nesoryzomys is quite distinct from all other Oryzomyini, including Aegialomys, karyologically (Gardner and Patton 1976), morphologically, phenetically, and electrophoretically (Patton and Hafner 1983). Galapagoan and mainland Aegialomys are extremely similar to each other karyologically (Gardner and Patton 1976), morphologically, phenetically, and electrophoretically (Patton and Hafner 1983). Sequence information for Galapagoan Aegialomys would be most welcome, although the close affinity between the insular and mainland species assigned to Aegialomys seems unassailable based on the other types of data. This close affinity between mainland and insular Aegialomys even led Patton and Hafner (1983) to hypothesize colonization of the Galapagos via pre-Columbian human transport.

Megalomys is the only genus shown, as a member of this clade, that does not have a trans-Andean distribution. Two species of Megalomys still occurred in the Lesser Antilles at least until the 1800s. Four named species (1 from Curaçao) are now recognized (Turvey et al. 2010). Regardless of the affinities of Megalomys, its supposed occurrence both in the eastern Lesser Antilles and on Curaçao is biogeographically anomalous and we concur with McFarlane and Lundberg (2002:280) that "the Megalomys spp. of the eastern Lesser Antilles are likely to have evolved from [a] mainland oryzomyine ancestor or ancestors independently of events on Curaçao, in which case the genus Megalomys as currently recognized would have to be regarded as a polyphyletic construct.' Also, as noted by Turvey et al. (2010), the animal known as Megalomys audreyae Hopwood, 1926, from Barbuda, may not belong in Megalomys.

Another potential member of this clade is Pennatomys, as based in the analyses of Turvey et al. (2010). The single described species of Pennatomys ( $P$. nivalis Turvey et al., 2010) occurred on Nevis, St. Eustatius, and St. Kitts in the Lesser Antilles at least until historic times, but there is now what is claimed to be evidence for the existence of a living species of native muroid on Nevis. The late James W. Johnson, a resident naturalist and nature guide on Nevis, provided color photographs, said to have been taken on Nevis, of a long-tailed rodent that could conceivably belong to the newly described genus Pennatomys or else to some other but as yet undescribed taxon (see text and photographs at Nevis Historical and Conservation Society [2010]). In the photographs provided, the animal has a pale gray dorsum, white venter, and a black, naked tail considerably longer than head plus body. We have examined specimens of Rattus rattus (Linnaeus, 1758) that approach this animal in coloration, and are not convinced that the rodent photographed could not belong to that species. Greater and Lesser Antillean species of Oryzomyini other than of Pennatomys have been placed in Megalomys, Oryzomys, and Oligoryzomys, but the Nevis animal looks like a member of none of these genera. Turvey et al. (2010:764) noted that Johnson had reported to them that there have been reports of "unusual-looking rats occurring on Nevis into recent times" and that they had been eaten by people there at least until the 1930s. An attempt to collect this mysterious rodent in 2009, however, recovered only the invasive $R$. rattus (S. T. Turvey, Zoological Society of London, pers. comm.).

The resolution of relationships among a number of genera and species that have not yet been studied in detail will shed further light on the biogeography and diversity of this interesting clade. In addition to individual mammalian species that have trans-Andean distributions, it is now becoming apparent that there are more supraspecific trans-Andean clades than had been previously recognized (e.g., this paper; Gutiérrez et al. 2010; Rossi et al. 2010).

\section{RESUMEN}

A partir de estudios recientes, profundizamos acerca de las relaciones filogenéticas dentro de Oryzomyini, en particular aquellas que involucran taxa actualmente atribuidos al género Sigmodontomys. Recientemente se ha considerado que Sigmodontomys incluye 2 especies, alfari (J. A. Allen, 1897) y aphrastus (Harris, 1932), sin embargo, a través de su complicada historia taxonómica, ambas especies también han sido incluidas dentro del género Oryzomys, y alfari independientemente dentro del género Nectomys. Usando caracteres morfológicos (98 externos, craneales, dentales y postcraneales) y moleculares (citocromo $b, 12 \mathrm{~S}$ y IRBP), inferimos la posición filogenética de estas 2 especies dentro de Oryzomyini. Documentamos que alfari y aphrastus no forman un grupo monofilético. Sigmodontomys alfari es el taxón hermano de Melanomys, mientras aphrastus es hermano de dicho grupo, o del género caribeño extinto Megalomys. Por consiguiente, consideramos a aphrastus como un nuevo género que describimos y nombramos a continuación. Este nuevo género está incluido dentro del clado formado por Sigmodontomys-MelanomysAegialomys-Nesoryzomys, el cual representa un grupo monofilético bien sustentado principalmente del sur de Centroamérica y norte de Sudamérica, restringido principalmente a hábitats de tierras bajas a elevaciones intermedias trasandinas, y caracterizado por su habilidad de cruzar barreras de agua salada. El nuevo género se encuentra en elevaciones medianas y altas desde el centro y norte de Costa Rica hasta el noroeste de Ecuador y, junto con algunas poblaciones de Aegialomys y Melanomys, ocupa las localidades más altas de cualquier miembro de este grupo.

\section{ACKNOWLEDGMENTS}

The Monteverde Cloud Forest Reserve and the Monteverde Conservation League graciously allowed RMT to conduct research in their reserves. J. Guevara Sequeira and El Sistema Nacional de Áreas de Conservación de Costa Rica-Ministerio del Ambiente y Energía provided permits for research. At Monteverde, R. LaVal and C. McCain greatly assisted RMT's efforts. B. Rodríguez-H. (MNCR and Universidad de Costa Rica) provided full access to the collections and the specimens deposited in those 2 collections. In Panama, J. S. Burt (then with RTZ Development Enterprises, Limited) provided 
extraordinary efforts on behalf of RHP's fieldwork, and R. J. Izor and J. Wagner assisted in the field. We thank R. P. Anderson and R. S. Voss for unselfishly providing us additional information on specimens they collected as well as providing access to specimens at AMNH. J. M. Chupasko assisted our research at MCZ and provided loans of specimens critical for study. At the USNM, M. Carleton, A. L. Gardner, L. Gordon, H. Kafka, N. Woodman, and the late C. O. Handley, Jr., made specimens available to us for study and our work there most productive. P. Myers and S. Hinshaw greatly assisted our research at UMMZ, and P. Myers graciously provided photographs and measurements of the holotype of T. aphrastus. J. D. Hanson provided unpublished IRBP sequences for Melanomys; C. R. Bonvicino, G. D'Elía, M. Fonseca, and M. Valqui provided critical tissues; S. Loss assisted with the morphological scoring of Melanomys; and B. L. Clauson, B. Morey, A. Falk, A. Romero, M. Soley, and P. Velazco assisted with the production of the manuscript. C. Ray provided us with a copy of his Ph.D. dissertation and gave extremely helpful insights. S. Pederson assisted us in evaluating specimens and reports from the Antilles and R. C. Dowler assisted us in evaluating the distribution of Oryzomyini in the Galapagos. C. O. Handley, Jr., B. K. Lim, U. F. J. Pardiñas, and R. S. Voss provided reviews of earlier drafts of the manuscript.

\section{Literature Cited}

Bonvicino, C. R., AND M. A. M. MoreIRA. 2001. Molecular phylogeny of the genus Oryzomys (Rodentia: Sigmodontinae) based on cytochrome $b$ DNA sequences. Molecular Phylogenetics and Evolution 18:282-292.

Bradley, R. D., C. W. Edwards, D. S. Carroll, and C. W. KilPATRICK. 2004. Phylogenetic relationships of neotomine-peromyscine rodents: based on DNA sequences from the mitochondrial cytochrome- $b$ gene. Journal of Mammalogy 85:389-395.

Cadena, A., R. P. Anderson, and P. Rivas-Pava. 1998. Colombian mammals from the Chocoan slopes of Nariño. Occasional Papers, The Museum, Texas Tech University 180:1-15.

Carleton, M. D. 1973. A survey of gross stomach morphology in New World Cricetinae (Rodentia, Muroidea), with comments on functional interpretations. Miscellaneous Publications of the Museum of Zoology, University of Michigan 146:1-43.

Carleton, M. D. 1980. Phylogenetic relationships in neotomineperomyscine rodents (Muroidea) and a reappraisal of the dichotomy within New World Cricetinae. Miscellaneous Publications of the Museum of Zoology, University of Michigan 157:1-152.

Carleton, M. D., and G. G. Musser. 1989. Systematic studies of oryzomyine rodents (Muridae, Sigmodontinae): a synopsis of Microryzomys. Bulletin of the American Museum of Natural History 191:1-83.

Carleton, M. D., and G. G. Musser. 1995. Systematic studies of oryzomyine rodents (Muridae: Sigmodontinae): definition and distribution of Oligoryzomys vegetus (Bangs, 1902). Proceedings of the Biological Society of Washington 108:338-369.

Carleton, M. D., and S. L. Olson. 1999. Amerigo Vespucci and the rat of Fernando de Noronha: a new genus and species of Rodentia (Muridae, Sigmodontinae) from a volcanic island off Brazil's continental shelf. American Museum Novitates 3256:1-59.

D’Elía, G. 2003. Phylogenetics of Sigmodontinae (Rodentia, Muroidea, Cricetidae), with special reference to the akodont group, and with additional comments on historical biogeography. Cladistics 19:307-323.

D’Elía, G., U. F. J. Pardiñas, P. Teta, and J. L. Patton. 2007. Definition and diagnosis of a new tribe of sigmodontine rodents (Cricetidae: Sigmodontinae), and a revised classification of the subfamily. Gayana 71:187-194.
Ellerman, J. R. 1941. The families and genera of living rodents with a list of named forms (1758-1936) by R. W. Hayman and G. W. C. Holt. Vol. II. Family Muridae. British Museum (Natural History), London, United Kingdom.

FARris, J. S. 1983. The logical basis of phylogenetic analysis. Pp. $7-$ 36 in Advances in cladistics (N. H. Platnick and V. A. Funk, eds.). Proceedings of the Second Meeting of the Willi Hennig Society. Columbia University Press, New York. Vol. 2.

Farris, J. S., V. A. Albert, M. Källersjö, D. Lipscomb, and A. G. KLUGE. 1996. Parsimony jackknifing outperforms neighbor-joining. Cladistics 12:99-124.

Felsenstein, J. 1981. Evolutionary trees from DNA sequences: a maximum likelihood approach. Journal of Molecular Evolution 17:368-376.

Felsenstein, J. 1985. Confidence limits on phylogenies: an approach using the bootstrap. Evolution 39:783-791.

Felsenstein, J. 2003. Inferring phylogenies. Sinauer Associates, Inc., Publishers, Sunderland, Massachusetts.

Gardner, A. L., And J. L. Patton. 1976. Karyotypic variation in oryzomyine rodents (Cricetinae) with comments on chromosomal evolution in the Neotropical cricetine complex. Occasional Papers of the Museum of Zoology, Louisiana State University 49:1-48.

Goodwin, G. G. 1946. Mammals of Costa Rica. Bulletin of the American Museum of Natural History 87:271-473.

GutiérRez, E. E., S. A. JansA, And R. S. Voss. 2010. Molecular systematics of mouse opossums (Didelphidae: Marmosa): assessing species limits using mitochondrial DNA sequences, with comments on phylogenetic relationships and biogeography. American Museum Novitates 3692:1-22.

HAFFER, J. 1987. Biogeography of Neotropical birds. Pp. 105-150 in Biogeography and Quaternary history in tropical America (T. C. Whitmore and G. T. Prance, eds.). Oxford Monographs on Biogeography 3. Clarendon Press, Oxford, United Kingdom.

Hall, E. R. 1981. The mammals of North America. 2nd ed. John Wiley \& Sons, New York.

Hall, E. R., and K. R. Kelson. 1959. The mammals of North America. 1st ed. Ronald Press Company, New York.

Hanson, J. D., AND R. D. BRadley. 2008. Molecular diversity within Melanomys caliginosus (Rodentia: Oryzomyini): evidence for multiple species. Occasional Papers, Museum of Texas Tech University 275:1-11.

Harris, W. P., JR. 1932. Four new mammals from Costa Rica. Occasional Papers of the Museum of Zoology, University of Michigan 248:1-6.

Hershrovitz, P. 1944. A systematic review of the Neotropical water rats of the genus Nectomys (Cricetinae). Miscellaneous Publications of the Museum of Zoology, University of Michigan 58:1-101.

Hershkovitz, P. 1948. Mammals of northern Colombia. Preliminary report no. 3: water rats (genus Nectomys), with supplemental notes on related forms. Proceedings of the United States National Museum 98:49-56.

Hershrovitz, P. 1962. Evolution of Neotropical cricetine rodents (Muridae) with special reference to the phyllotine group. Fieldiana: Zoology 46:1-510.

Hershkovitz, P. 1970. Supplementary notes on Neotropical Oryzomys dimidiatus and Oryzomys hammondi (Cricetinae). Journal of Mammalogy 51:789-794.

Hooper, E. T., and G. G. Musser. 1964. The glans penis in Neotropical cricetines (family Muridae) with comments on classification of muroid rodents. Miscellaneous Publications of the Museum of Zoology, University of Michigan 123:1-57.

Huelsenbeck, J. P., And F. Ronquist. 2001. MRBAYES: Bayesian inference of phylogenetic trees. Bioinformatics 17:754-755. 
Huelsenbeck, J. P., F. Ronquist, R. Nielsen, and J. P. Bollback. 2001. Bayesian inference of phylogeny and its impact on evolutionary biology. Science 294:2310-2314.

JANSA, S. A., AND M. WEKSLER. 2004. Phylogeny of muroid rodents: relationships within and among major lineages as determined by IRBP gene sequences. Molecular Phylogenetics and Evolution 31:256-276.

KOCHER, T. D., ET AL. 1989. Dynamics of mitochondrial DNA evolution in animals: amplification and sequencing with conserved primers. Proceedings of the National Academy of Sciences 86:6196-6200.

LeE, T. E., Jr., S. F. Burneo, T. J. Cochran, and D. Chávez. 2010. Small mammals of Santa Rosa, southwestern Imbabura Province, Ecuador. Occasional Papers, Museum of Texas Tech University 290:1-14.

LewIS, P. O. 2001. A likelihood approach to estimating phylogeny from discrete morphological character data. Systematic Biology 50:913-925.

McCain, C. M., R. M. Timm, And M. WeKsler. 2007. Redescription of the enigmatic long-tailed rat Sigmodontomys aphrastus (Cricetidae: Sigmodontinae) with comments on taxonomy and natural history. Proceedings of the Biological Society of Washington 120:117-136.

McFarlane, D. A., AND J. LundBerg. 2002. A middle Pleistocene age and biogeography for the extinct rodent Megalomys curazensis from Curaçao, Netherlands Antilles. Caribbean Journal of Science 38:278-281.

MÉndez, E. 1993. Los roedores de Panamá. Privately published, Cíudadde Panama, Panama.

Musser, G. G., And M. D. Carleton. 1993. Family Muridae. Pp. 501755 in Mammal species of the world: a taxonomic and geographic reference (D. E. Wilson and D. M. Reeder, eds.). 2nd ed. Smithsonian Institution Press, Washington, D.C.

Musser, G. G., and M. D. Carleton. 2005. Superfamily Muroidea. Pp. 894-1531 in Mammal species of the world: a taxonomic and geographic reference (D. E. Wilson and D. M. Reeder, eds.). 3rd ed. Johns Hopkins University Press, Baltimore, Maryland.

Musser, G. G., M. D. Carleton, E. M. Brothers, and A. L. Gardner. 1998. Systematic studies of oryzomyine rodents (Muridae, Sigmodontinae): diagnoses and distributions of species formerly assigned to Oryzomys "capito.' Bulletin of the American Museum of Natural History 236:1-376.

Musser, G. G., And M. M. Williams. 1985. Systematic studies of oryzomyine rodents (Muridae): definitions of Oryzomys villosus and Oryzomys talamancae. American Museum Novitates 2810:1-22.

Nevis Historical and Conservation Society. 2010. "Extinct'” rodent discovered on Nevis? http://www.bio-diversity-nevis.org/toppage1. htm. Accessed 1 March 2011.

PARdiñas, U. F. J. 2008. A new genus of oryzomyine rodent (Cricetidae: Sigmodontinae) from the Pleistocene of Argentina. Journal of Mammalogy 89:1270-1278.

Pardiñas, U. F. J., G. D’Elía, and P. E. Ortiz. 2002. Sigmodontinos fósiles (Rodentia, Muroidea, Sigmodontinae) de América del Sur: estado actual de su conocimiento y prospectiva. Mastozoología Neotropical 9:209-252.

Patton, J. L., And M. S. Hafner. 1983. Biosystematics of the native rodents of the Galapagos Archipelago, Ecuador. Pp. 539-568 in Patterns of evolution in Galapagos organisms (R. I. Bowman, M. Benson, and A. E. Leviton, eds.). Pacific Division, American Association for the Advancement of Science, San Francisco, California.

Percequillo, A. R., M. Weksler, and L. P. Costa. 2011. A new genus and species of rodent from the Brazilian Atlantic Forest (Rodentia, Cricetidae, Sigmodontinae, Oryzomyini), with comments on oryzomyine biogeography. Zoological Journal of the Linnean Society 161:357-390.
Rambaut, A., And A. J. Drummond. 2007. Tracer v1.4. http://beast. bio.ed.ac.uk/Tracer. Accessed 1 December 2008.

RAY, C. E. 1962. Oryzomyine rodents of the Antillean subregion. Ph.D. dissertation, Harvard University, Cambridge, Massachusetts.

ReID, F. A. 1997. A field guide to the mammals of Central America and southeast Mexico. 1st ed. Oxford University Press, New York.

ReID, F. A. 2009. A field guide to the mammals of Central America \& southeast Mexico. 2nd ed. Oxford University Press, New York.

ReIG, O. A. 1977. A proposed unified nomenclature for the enamelled components of the molar teeth of the Cricetidae (Rodentia). Journal of Zoology (London) 181:227-241.

RiDGWAY, R. 1912. Color standards and color nomenclature. Privately published, Washington, D.C.

Rodríguez, F., J. L. Oliver, A. Marín, and J. R. Medina. 1990. The general stochastic model of nucleotide substitution. Journal of Theoretical Biology 142:485-501.

Ronquist, F., AND J. P. Huelsenbeck. 2003. MRBAYES 3: Bayesian phylogenetic inference under mixed models. Bioinformatics 19:1572-1574.

Rossi, R. V., R. S. Voss, And D. P. Lunde. 2010. A revision of the didelphid marsupial genus Marmosa. Part 1. The species in Tate's 'mexicana' and 'mitis' sections and other closely related forms. Bulletin of the American Museum of Natural History 334:1-83.

Salazar-Bravo, J., and T. L. Yates. 2007. A new species of Thomasomys (Cricetidae: Sigmodontinae) from central Bolivia. Pp. 747-774 in The quintessential naturalist: honoring the life and legacy of Oliver $\mathrm{P}$. Pearson (D. A. Kelt, E. P. Lessa, J. Salazar-Bravo, and J. L. Patton, eds.). University of California Publications in Zoology 134:1-981.

Sikes, R. S., W. L. Gannon, and the Animal Care and Use Committee of the American Society of Mammalogists. 2011. Guidelines of the American Society of Mammalogists for the use of wild mammals in research. Journal of Mammalogy 92:235-253.

Smith, M. F., and J. L. Patton. 1993. The diversification of South American murid rodents: evidence from mitochondrial DNA sequence data for the akodontine tribe. Biological Journal of the Linnean Society 50:149-177.

Smith, M. F., And J. L. Patton. 1999. Phylogenetic relationships and the radiation of sigmodontine rodents in South America: evidence from cytochrome $b$. Journal of Mammalian Evolution 6:89-128.

Stamatakis, A. 2006a. Phylogenetic models of rate heterogeneity: a high performance computing perspective. Proceedings of the 20th International Parallel and Distributed Processing Symposium (IPDPS2006). Rhodes Island, Greece.

STAMATAKIS, A. 2006b. RAxML-VI-HPC: maximum likelihood-based phylogenetic analyses with thousands of taxa and mixed models. Bioinformatics 22:2688-2690.

Steadman, D. W., and S. Zousmer. 1988. Galapágos: discovery on Darwin's islands. Smithsonian Insitituion Press, Washington, D.C.

Steppan, S. J. 1995. Revision of tribe Phyllotini (Rodentia: Sigmodontinae), with a phylogenetic hypothesis for the Sigmodontinae. Fieldiana: Zoology (New Series) 80:1-112.

Steppan, S. J., R. M. Adkins, And J. Anderson. 2004. Phylogeny and divergence-date estimates of rapid radiations in muroid rodents based on multiple nuclear genes. Systematic Biology 53:533-553.

Swofford, D. L. 2001. PAUP*: phylogenetic analysis using parsimony (*and other methods). Version 4.0b10. Sinauer Associates, Inc., Publishers, Sunderland, Massachusetts.

Swofford, D. L., G. J. Olsen, P. J. Waddell, and D. M. Hillis. 1996. Phylogenetic inference. Pp. 407-514 in Molecular systematics (D. M. Hillis, C. Moritz, and B. K. Mable, eds.). 2nd ed. Sinauer Associates, Inc., Publishers, Sunderland, Massachusetts. 
TiRIRA, D. 2008. Mamíferos de los bosques húmedos del noroccidente de Ecuador. Ediciones Murciélago Blanco y Proyecto PRIMENET. Publicación Especial Sobre los Mamíferos del Ecuador 7. Quito, Ecuador.

Turvey, S. T., M. Weksler, E. L. Morris, and M. Nokkert. 2010. Taxonomy, phylogeny, and, diversity of the extinct Lesser Antillean rice rats (Sigmodontinae: Oryzomyini), with description of a new genus and species. Zoological Journal of the Linnean Society 160:748-772.

Voss, R. S. 1988. Systematics and ecology of ichthyomyine rodents (Muroidea): patterns of morphological evolution in a small adaptive radiation. Bulletin of the American Museum of Natural History 188:259-493.

Voss, R. S. 1993. A revision of the Brazilian muroid rodent genus Delomys with remarks on 'thomasomyine' characters. American Museum Novitates 3073:1-44.

Voss, R. S., And M. D. Carleton. 1993. A new genus for Hesperomys molitor Winge and Holochilus magnus Hershkovitz (Mammalia, Muridae) with an analysis of its phylogenetic relationships. American Museum Novitates 3085:1-39.

Voss, R. S., AND A. V. LinzeY. 1981. Comparative gross morphology of male accessory glands among Neotropical Muridae (Mammalia: Rodentia) with comments on systematic implications. Miscellaneous Publications of the Museum of Zoology, University of Michigan 159:1-41.

Voss, R. S., And M. WeKsLer. 2009. On the taxonomic status of Oryzomys curasoae McFarlane and Debrot, 2001, with remarks on the phylogenetic relationships of O. gorgasi Hershkovitz, 1971. Caribbean Journal of Science 45:73-79.

WeKsLER, M. 2003. Phylogeny of Neotropical oryzomyine rodents (Muridae: Sigmodontinae) based on the nuclear IRBP exon. Molecular Phylogenetics and Evolution 29:331-349.

WeKSLER, M. 2006. Phylogenetic relationships of oryzomyine rodents (Muroidea: Sigmodontinae): separate and combined analysis of morphological and molecular data. Bulletin of the American Museum of Natural History 296:1-149.

Weksler, M., and A. R. Percequillo. 2011. Key to the genera of the tribe Oryzomyini (Rodentia: Cricetidae: Sigmodontinae). Mastozoología Neotropical 18:281-292.

Weksler, M., A. R. Percequillo, and R. S. Voss. 2006. Ten new genera of oryzomyine rodents (Muridae: Sigmodontinae). American Museum Novitates 3537:1-29.

WIENS, J. J. 1995. Polymorphic characters in phylogenetic systematics. Systematic Biology 44:482-500.
YANG, Z. 1994. Statistical properties of the maximum likelihood method of phylogenetic estimation and comparison with distance matrix methods. Systematic Biology 43:329-342.

YANG, Z., AND B. Rannala. 1997. Bayesian phylogenetic inference using DNA sequences: a Markov chain Monte Carlo method. Molecular Biology and Evolution 14:717-724.

Zijlstra, J. S., P. A. Madern, and L. W. van den Hoek Ostende. 2010. New genus and two new species of Pleistocene oryzomyines (Cricetidae: Sigmodontinae) from Bonaire, Netherlands Antilles. Journal of Mammalogy 91:860-873.

Submitted 12 January 2011. Accepted 62012.

Associate Editor was Burton K. Lim.

\section{Appendix I}

List of newly analyzed specimens of taxa included in phylogenetic analyses. Other specimens analyzed were listed previously by Weksler (2006), Turvey et al. (2010), and Percequillo et al. (2011).

Tanyuromys aphrastus.-COSTA RICA: Alajuela/Puntarenas; Monteverde Cloud Forest Reserve (KU 159021, 161003). San José; San Joaquín de Dota (UMMZ 62875). ECUADOR: Pichincha; Guarumos (MCZ 50396); Pichincha; Mindo (UMMZ 155808). PANAMA: Chiriquí, 24 km NNE San Félix (USNM 541200, 541201).

Rhipidomys nitela.-VENEZUELA: Bolívar; $12 \mathrm{~km}$ SW San Ignacio de Yuruani (AMNH 257273-257275). FRENCH GUIANA: Sinnamary; Paracou (AMNH 267021, 267582, 267583, 267594); Les Nouragues (AMMH 269821).

Melanomys caliginosus._ECUADOR: Esmeraldas; Esmeraldas (AMNH 33216, 33219, 33220); Manabí; Cuaque (AMNH 66331, 66333, 66335, 66338, 66340); Pichincha; Gualea (AMNH 46689, 46691, 46696); Pichincha; Las Maquinas (AMNH 66326, 66327, 66329, 66330); Guayas; Río Pescado (AMNH 61967).

Melanomys chrysomelas._COSTA RICA: Limón; Suerre (AMNH 10777); Puntarenas; Palmar (AMNH 139412, 139416, 139419, 139421, 139423); San José; San Geronimo Pieris (AMNH 123559 123561). NICARAGUA: Río Tuma (AMNH 28394, 28404, 29529, 29532); Chontales (AMNH 28556, 28557). PANAMA: Bocas del Toro (USNM 464387, 464388, 464390, 464391, 464877, 464878, 464880, 464883, 503716, 575658, 575660, 578384, 578385). 


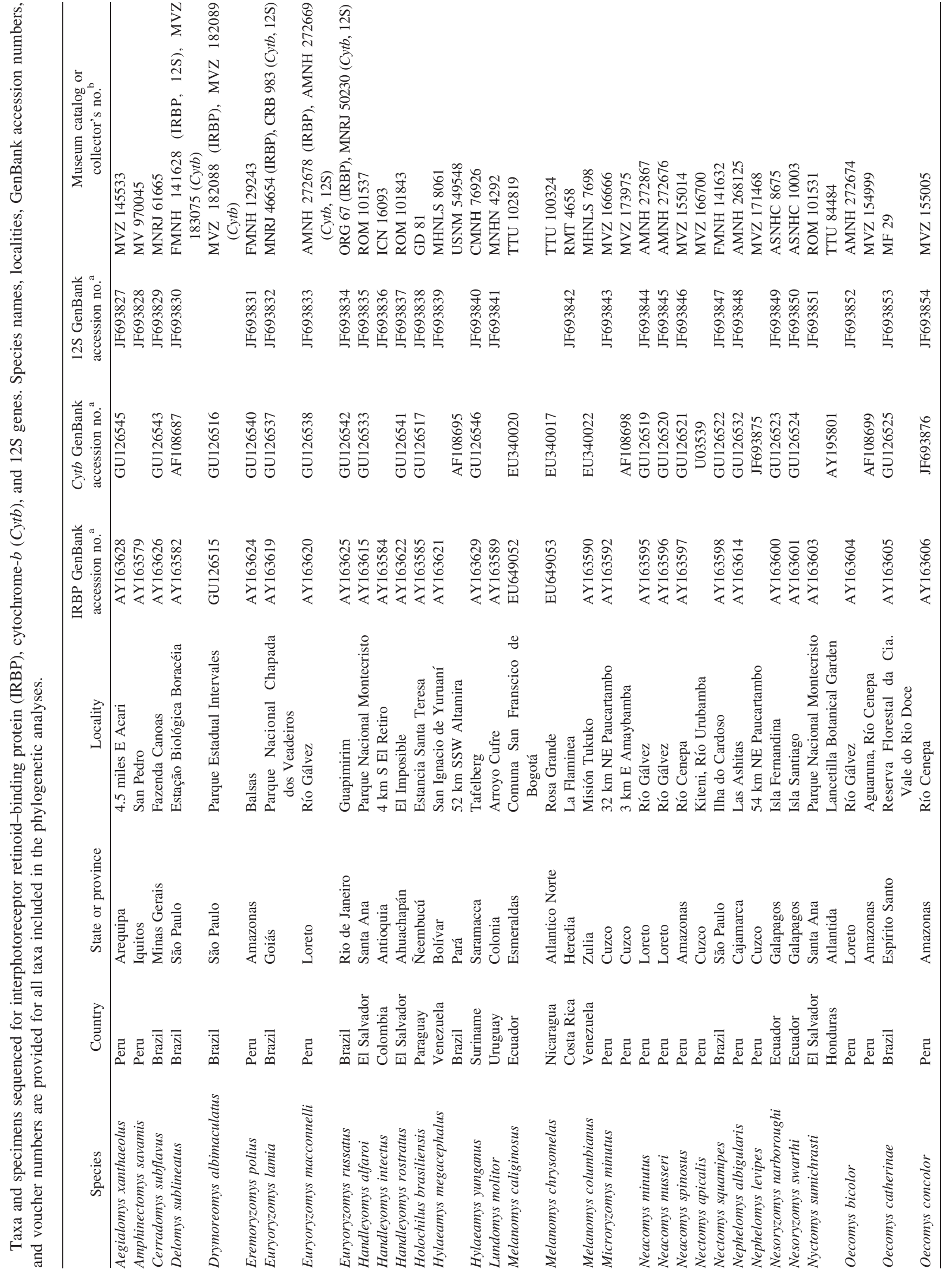




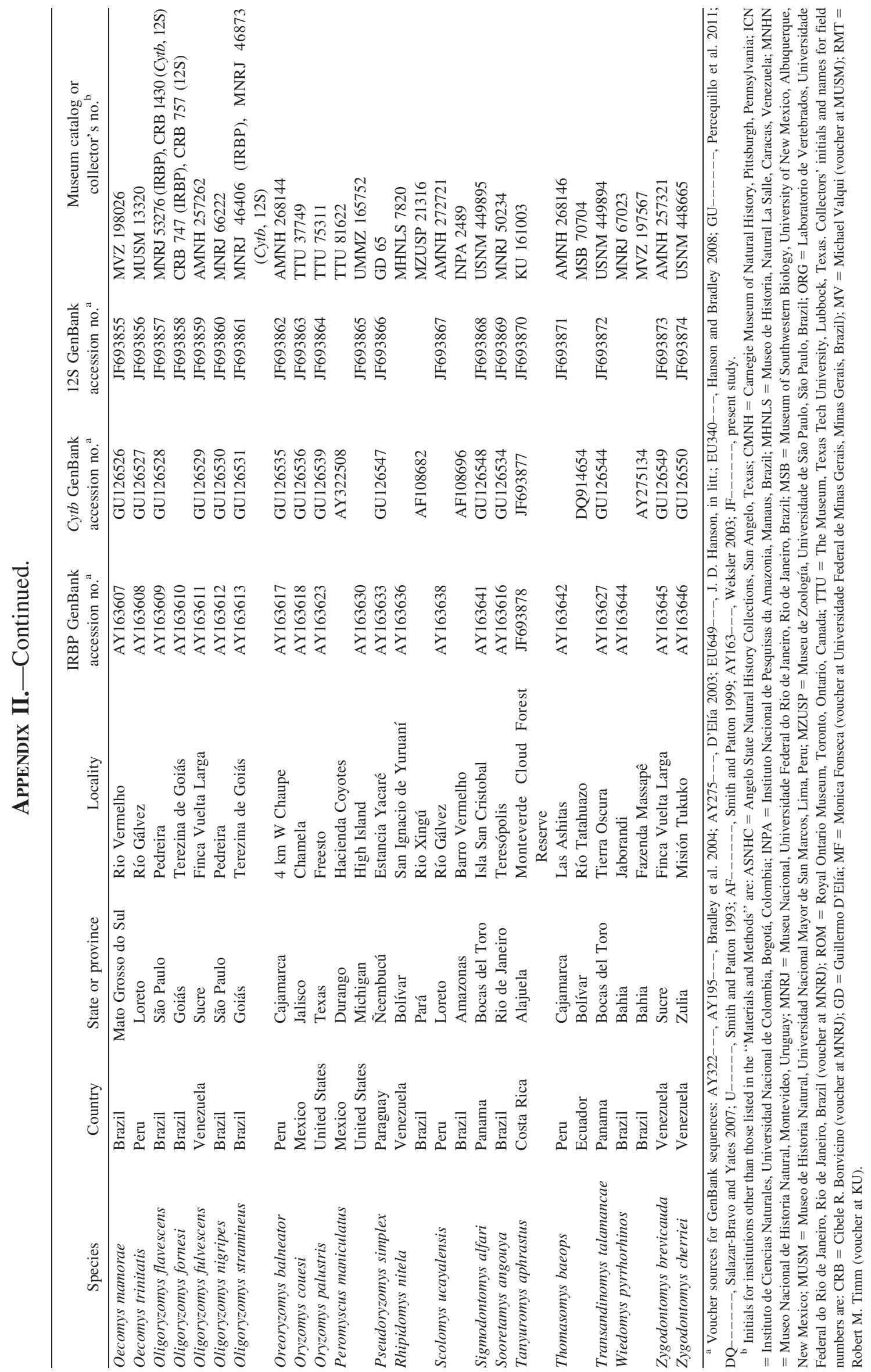

